(C) 2015 Elsevier B.V. This manuscript version is made available under the CC-BY-NC-ND 4.0 license http://creativecommons.org/licenses/by-nc-nd/4.0/

\title{
The cross-sectional variation of volatility risk premia*
}

\author{
Journal of Financial Economics 119, 2016, 353-370 \\ Ana González-Urteaga ${ }^{\mathrm{a}}$, Gonzalo Rubio ${ }^{\mathrm{b}, *}$ \\ a Department of Business Management, Public University of Navarra, Campus \\ Arrosadía, 31006 Pamplona, Spain \\ ${ }^{b}$ Department of Economics and Business, University CEU Cardenal Herrera, Reyes \\ Católicos 19, 03204 Elche, Alicante, Spain
}

\begin{abstract}
This paper analyzes the determinants of the cross-sectional variation of the average volatility risk premia for a representative set of portfolios sorted by volatility risk premium beta. The market volatility risk premium and, especially, the default premium are shown to be key risk factors in the cross-sectional variation of average volatility risk premium payoffs. The cross-sectional variation of risk premia seems to reflect a very different behavior of the underlying components of our sample portfolios with respect to credit or financial stress that generates a significant dispersion of the volatility swap pricing of these securities.
\end{abstract}

This version: September 2, 2015

JEL classification: G11, G12, G13

Keywords: Volatility risk premia; Stochastic discount factor; Consumption-based models; Linear factor models; Default premium

\footnotetext{
*We thank Javier Gil-Bazo, Belén Nieto, Roberto Pascual, Javier Perote, Pedro Serrano, James Sinclair, an anonymous referee, and seminar participants at Pompeu Fabra, Carlos III and Islas Baleares Universities, the Eighth Portuguese Finance Association International Conference, and the XXII Finance Forum at the University of Zaragoza (Spain). We acknowledge financial support from the Ministry of Economics and Competitiveness through grant ECO2012-34268. In addition, Gonzalo Rubio acknowledges financial support from Generalitat Valenciana grant PROMETEOII/2013/015, and Ana González-Urteaga acknowledges financial support from ECO2012-35946.

*Corresponding author, Tel.: (34) 965426486; Fax: (34) 965459561.

E-mail address: gonzalo.rubio@uch.ceu.es (G. Rubio).
} 


\section{Introduction}

Since the seminal paper of Bakshi and Kapadia (2003a), the market variance risk premium has been reported to be negative, on average, during alternative sample periods. ${ }^{1}$ Given that the payoff of a variance swap contract is the difference between the realized variance and the variance swap rate, negative returns to long positions on variance swap contracts for all time horizons mean that investors are willing to accept negative returns for purchasing realized variance. Equivalently, investors who are sellers of variance and are providing insurance to the market require positive returns. This could be rational, as the correlation between volatility shocks and market returns is known to be strongly negative and investors want protection against stock market crashes. Along these lines, Bakshi and Madan (2006) and Chabi-Yo (2012) show theoretically that the skewness and kurtosis of the underlying market index are key determinants of the market variance risk premium. Bakshi and Madan (2006), Bollerslev, Gibson, and Zhou (2011), Bekaert and Hoerova (2013), and Bekaert, Hoerova, and Lo Duca (2013) argue that the market variance risk premium is an indicator of aggregate risk aversion. ${ }^{2}$ Zhou (2010) shows that the market variance risk premium significantly predicts short-run equity returns, bond returns, and credit spreads. Consequently, the author argues that risk premia in major markets co-move in the short run and that such co-movement seems to be related to the market variance risk premia. Finally, Campbell, Giglio, Polk, and Turley (2014), using an intertemporal capital asset pricing model (ICAPM) framework, argue that co-variation with aggregate volatility

\footnotetext{
${ }^{1}$ For additional empirical evidence of the negative variance risk premium on the market index, see Carr and $\mathrm{Wu}$ (2009) and the papers cited in their work.

${ }^{2}$ A related interpretation is due to Bollerslev, Tauchen, and Zhou (2009) and Drechsler and Yaron (2011), who interpret the market variance risk premium as a proxy of macroeconomic risk (consumption uncertainty). They show that time-varying economic uncertainty and a preference for the early resolution of uncertainty are required to generate a negative market variance risk premium.
} 
news has a negative premium. At this point, it is fair to argue that the behavior of the market variance risk premium and its implications for financial economics are understood.

However, surprisingly little is known about the variance risk premium at the individual level. Bakshi and Kapadia (2003b) show that the variance risk premium is also negative in individual equity options. But, as Driessen, Maenhout, and Vilkov (2009) find, the variance risk premium for stock indices is systematically larger, that is, more negative, than for individual securities. They argue that the variance risk premium can, in fact, be interpreted as the price of time-varying correlation risk. They show that the market variance risk is negative only to the extent that the price of the correlation risk is negative. In a related paper, Buraschi, Trojani, and Vedolin (2014) argue that the wedge between index and volatility risk premia is explained by investor disagreement. Hence, the greater the differences in beliefs among investors, the larger the market volatility risk relative to the volatility risk premium of individual options. Even these papers are particularly concerned with the behavior of the market variance risk premium, despite employing data at the individual level.

We argue that an analysis and understanding of the time series and cross-sectional behavior of the variance risk premium at the individual level is lacking in the previous literature. This paper partially covers this gap. Our main contribution is to analyze the cross-sectional variation of the volatility risk premium $(V R P)$ at the portfolio level. We employ daily data from OptionMetrics for the Standard \& Poor's (S\&P) 100 Index options and for individual options on 181 stocks included at some point in the S\&P 100 Index during the sample period from January 1996 to February 2011. We calculate the VRP for each stock at the 30-day horizon as the difference between the corresponding realized volatility and the model-free implied volatility described by Jiang and Tian (2005). 
Similarly, we estimate the market $V R P$ using the S\&P 100 Index as the underlying index. For each month, we construct 20 equally weighted portfolios ranking the individual $V R P$ values according to their betas with respect to the market VRP. These volatility risk premium betas are estimated over the previous month with daily data. The main objective of the paper is to analyze the determinants of the cross-sectional variation of the VRP of our 20 VRP beta-sorted portfolios.

The betas of the VRP beta-sorted portfolios estimated with respect to the market VRP range from -0.95 to 3.89 . The portfolio with the most negative beta has the highest average $V R P$, and the two portfolios with higher positive beta present the most negative average $V R P$. Therefore, we find both negative and positive average $V R P$ values ranging from 0.103 to -0.035 on an annual basis while the average market $V R P$ is negative, as in previous literature.

Regarding the cross-sectional variation of the $V R P$, we find that consumption risk under the recursive preferences of Epstein and Zin (1991) does not seem to explain the cross-sectional behavior of $V R P$. Factor asset pricing models seem to be more useful in explaining $V R P$ at the cross section. The key factors explaining average $V R P$ across our 20 portfolios are the market $V R P$ and, in addition, the default premium. The risk premia associated with the default premium betas are positive and statistically significant, even if we explicitly recognize the potential misspecification of the models. Moreover, we cannot reject the overall specification of the two-factor model, and the cross-sectional $R^{2}$ is equal to 0.514 , with an asymptotic standard error of 0.211 . Finally, our findings are related to credit risk and financial market stress conditions. The cross-sectional variations of volatility 
risk premia reflects the different uses of volatility swaps to hedge default and the financial stress risks of the underlying components of our sample portfolios.

This paper is organized as follows. Section 2 briefly describes variance swaps and volatility swap contracts and presents the alternative asset pricing models that we employ in the study of the cross-sectional variation of average VRP. Section 3 contains a description of the data. Section 4 discusses the model-free implied volatility and the estimation of $V R P$ at the portfolio level. Section 5 presents the basic characteristics of the $20 \mathrm{VRP}$ beta-sorted portfolios and empirical results using unconditional VRP beta estimates. Section 6 reports the main empirical findings of the paper and discusses the econometric strategy. Section 7 relates our evidence to financial stress conditions. Section 8 concludes the paper.

\section{Theoretical framework}

In a variance swap, the buyer of this forward contract receives at expiration a payoff equal to the difference between the annualized variance of stock returns and the fixed swap rate. The swap rate is chosen such that the contract has zero present value, which implies that the variance swap rate represents the risk-neutral expected value of the realized return variance:

$E_{t}^{Q}\left(R V_{t, t+1}^{i}\right)=S W_{t, t+1}^{i}$

where $E_{t}^{Q}($.$) is the time t$ conditional expectation operator under a given risk-neutral measure $Q, R V_{t, t+1}^{i}$ is the realized variance of asset (or portfolio) $i$ between $t$ and $t+1$, and $S W_{t, t+1}^{i}$ is the delivery price for the variance or the variance swap rate on the underlying asset $i$. The variance risk premium of asset $i$ is defined as 
$\operatorname{VARP} P_{t, t+1}^{i}=E_{t}^{P}\left(R V_{t, t+1}^{i}\right)-E_{t}^{Q}\left(R V_{t, t+1}^{i}\right)$.

At expiration, a volatility swap pays the holder the difference between the annualized volatility and the volatility swap rate,

$N_{v o l}\left(R V O L_{t, t+1}^{i}-S W V_{t, t+1}^{i}\right)$,

where $R V O L_{t, t+1}^{i}$ is the realized volatility of asset $i$ between $t$ and $t+1, S W V_{t, t+1}^{i}$ is the fixed volatility swap rate, and $N_{\text {vol }}$ denotes the volatility notional. This paper analyzes the determinants of the cross-sectional variation of volatility risk premia. We therefore define the volatility risk premium of asset $i$ as

$V R P_{t, t+1}^{i}=E_{t}^{P}\left(R V O L_{t, t+1}^{i}\right)-E_{t}^{Q}\left(R V O L_{t, t+1}^{i}\right)$.

Using the fundamental asset pricing equation, the risk premium of any asset $i$ with rate of return $R_{t}^{i}$ is given by

$$
R P_{t, t+1}^{i}=-\frac{\operatorname{Cov}_{t}^{P}\left(M_{t, t+1}, R_{t, t+1}^{i}\right)}{E_{t}^{P}\left(M_{t, t+1}\right)},
$$

where $M_{t, t+1}$ is the stochastic discount factor (SDF). Therefore, given the definition of the volatility risk premium, the following expression holds:

$E_{t}^{Q}\left(R V O L_{t+1}^{i}\right)=E_{t}^{P}\left(R V O L_{t+1}^{i}\right)+\frac{\operatorname{Cov}_{t}^{P}\left(M_{t, t+1}, R V O L_{t, t+1}^{i}\right)}{E_{t}^{P}\left(M_{t, t+1}\right)}$.

Thus, using the payoff of a volatility swap, the fundamental pricing framework implies that

$E_{t}^{P}\left\lfloor M_{t, t+1}\left(R V O L_{t, t+1}^{i}-S W V_{t, t+1}^{i}\right)\right\rfloor=E_{t}^{P}\left\lfloor M_{t, t+1}\left(V R P_{t, t+1}^{i}\right)\right\rfloor=0$.

The lack of empirical evidence explaining why the volatility risk premia are different in the cross section encourages a comprehensive analysis using as many models as possible and a full battery of SDFs. However, we should also be concerned with model proliferation. A 
huge number of papers have analyzed the cross section of equity returns. Harvey, Liu, and Zhu (2014) catalog 315 aggregate risk factors proposed in this vast literature. Using a multiple testing framework, these authors argue that a newly proposed factor needs a higher hurdle, with a $t$-ratio clearly higher than 2.0 to be accepted as a trustworthy new risk factor. Their paper follows a clear trend that we observe in the most recently published papers on the cross-sectional variation of expected returns. Researchers are much more careful now in assessing their empirical findings. A relevant example is Lewellen, Nagel, and Shanken (2010), who critique the traditional use of cross-sectional $R^{2}$ values and point out the pitfalls in evaluating the cross-sectional fit in popular asset pricing statistical tests.

In this paper, we equilibrate the potential danger of model proliferation with a parsimonious approach to present the most informative results about the cross-sectional variation of volatility risk premia.

We analyze both consumption-based and factor-based model specifications. Regarding consumption risk, we know, at least from a time series point of view, that the available approaches to generating realistic market variance risk premium dynamics usually involve recursive preferences combined with alternative processes for consumption growth or volatility of consumption growth, or both. Hence, the first SDF used in this research is based on recursive preferences with either the consumption growth of nondurable goods and services or stockholder consumption growth. The non-observable continuation value is approximated by either the return on the market portfolio or the market volatility risk premium.

We also employ linear SDF specifications based on state variables capable of explaining the cross-sectional variation of volatility swaps. The first factor-based model 
assumes that the SDF is linear on both the market return and the squared return of aggregate wealth:

$M_{t, t+1}=a+b R_{m t+1}+c R_{m t+1}^{2}$.

Recent empirical work has consistently shown that risk-neutral volatility is higher, on average, than physical return volatility. Little work has been done on characterizing theoretically the distance between both types of volatility, with Bakshi and Madan (2006) and Chabi-Yo (2012) being two exceptions. In both cases, the market variance risk premium is derived as a function of the standard deviation, skewness, and kurtosis of equity returns. Therefore, the magnitude and behavior over time of the market variance risk premium can also be empirically related to higher-order moments of the equity return distribution. This suggests that a potentially relevant model to explain the cross-sectional variation of volatility risk premia should explicitly recognize higher-order moments of the underlying market portfolio return. Bakshi and Madan (2006) show that when the SDF is a linear function on both the market return and the squared market return, as in expression (8), then the variance risk premium is a function of both the skewness and kurtosis of the market with $\partial M / \partial R_{m}<0$ and $\partial^{2} M / \partial R_{m}^{2}>0$.

In the second factor-based model, the SDF is linear on the market volatility risk premium denoted by $V R P_{t+1}^{m}$ :

$M_{t, t+1}=a+b V R P_{t+1}^{m}$

This could be justified by noting that Bali and Zhou (2015) show that the cross section of equity return portfolios is explained by the market, as well as by economic uncertainty proxied by the market variance risk premium. 
The third factor-based model is a two-factor model in which the SDF is linear on the market volatility risk premium and the default premium is the difference between Moody's yield on Baa corporate bonds and the ten-year government bond yield, denoted $D E F_{t+1}$ :

$$
M_{t, t+1}=a+b V R P_{t+1}^{m}+c D E F_{t+1} .
$$

The economic rationale of this model comes from the findings of Zhou (2010) and Wang, Zhou, and Zhou (2013), who show that the firm-level variance risk premium has significant explanatory power for credit default swap spreads over and above the market variance risk premium and the VIX (Chicago Board Options Exchange Market Volatility Index). The predictive ability increases as the credit quality of the credit default swap underlying companies deteriorates.

\section{Data}

We employ daily data from OptionMetrics for the S\&P 100 Index options and for individual options on all stocks included in the S\&P 100 Index at some point during the sample period from January 1996 to February 2011. This yields a total of 181 stocks used in our estimations. From the OptionMetrics database, we obtain all put and call options on the individual stocks and on the index with time to maturity $\tau$ between six days and 60 days. Given that the options are American style, it is convenient to work with short-term maturity options, for which the early exercise premium tends to be negligible. ${ }^{3}$ We select the best bid and ask closing quotes to calculate the mid-quotes as the average of bid and ask prices, not actual transaction prices, to avoid the well-known bid-ask bounce problem described by Bakshi, Cao, and Chen (1997). In selecting our final option sample, we apply

\footnotetext{
${ }^{3}$ See the evidence reported by Driessen, Maenhout, and Vilkov (2009), who employ a similar database.
} 
the usual filters. We discard options with zero open interest, zero bid prices, missing delta or implied volatility, and negative implied volatility. Regarding the exercise level, we follow Jiang and Tian (2005) and Driessen, Maenhout, and Vilkov (2009) and exclude inthe-money options. We employ calls with a delta lower than 0.5 and puts with a delta higher (less negative) than -0.5. In addition, we ignore options with extreme moneyness, that is, puts with a delta higher than -0.05 and calls with a delta lower than 0.05 .

It seems reasonable to expect that aggregate macroeconomic variables and marketwide portfolios extensively used by researchers when explaining the time series and crosssectional behavior of excess equity returns should also be relevant factors in explaining variance risk premia across assets. This is the main criterion we follow when collecting our data. As our option data, the market return for the S\&P 100 Index and individual stock returns and dividends are also obtained from OptionMetrics, and portfolio return data are from Kenneth French's website. ${ }^{4}$ We collect monthly data on the value-weighted stock market portfolio return, the risk-free rate, the SMB (small minus big) and HML (high minus low) Fama and French risk factors, and the momentum factor (MOM).

In addition, yields for ten-year government bonds, one-month T-bills, and Moody's Baa corporate bonds are obtained from the Federal Reserve Statistical Release. The default premium (DEF) is the difference between Moody's yield on Baa corporate bonds and the ten-year government bond yield.

We obtain nominal consumption expenditures on nondurable goods and services, population data, and the price deflator with the year 2000 as its basis from the National Income and Product Accounts (NIPA), available at the Bureau of Economic Analysis. All this information is used to construct monthly rates of growth of seasonally adjusted real per

\footnotetext{
${ }^{4}$ http://mba.tuck.dartmouth.edu/pages/faculty/ken.french/.
} 
capita consumption expenditures on nondurable goods and services from January 1960 to February 2011. We also use aggregate per capita stockholder consumption growth rates from the reported estimated coefficients of Malloy, Moskowitz, and Vissing-Jorgensen (2011) to obtain the factor-mimicking portfolio for stockholder consumption from January 1960 to February 2011.

\section{Model-free implied volatility and estimation of the volatility risk premia}

Britten-Jones and Neuberger (2000) first derived the model-free option implied volatility under diffusion assumptions. They obtain the risk-neutral expected integrated variance over the life of the option contract when prices are continuous and volatility is stochastic. Jiang and Tian (2005) extend their paper to show that their method is also valid in a jump-diffusion framework and, therefore, their methodology is considered to be a model-free procedure.

We calculate the model-free implied variance denoted $M F I V_{t, t+\tau}^{i}$ by the following integral over a continuum of strikes:

$M F I V_{t, t+\tau}^{i}=2 \int_{0}^{\infty} \frac{C_{t, t+\tau}^{i}(K) / B(t, t+\tau)-\max \left(S_{t}^{i} / B(t, t+\tau)-K, 0\right)}{K^{2}} d K$,

where $C_{t, t+\tau}^{i}(K)$ is the price at time $t$ of a $\tau$-maturity call option on either an asset or an index $i$ with strike $K, B(t, t+\tau)$ is the time $t$ price of a zero-coupon bond that pays $\$ 1$ at time $t+\tau$, and $S_{t}^{i}$ is the spot price of asset $i$ at time $t$ minus the present value of all expected future dividends to be paid before the option maturity. Expression (11) can be accurately approximated by the following sum over a finite number of strikes: 
$\operatorname{MFIV} V_{t, t+\tau}^{i} \cong \sum_{j=1}^{m}\left[g_{t, t+\tau}^{i}\left(K_{j}\right)+g_{t, t+\tau}^{i}\left(K_{j-1}\right)\right] \Delta K$

where

$$
\Delta K=\frac{\left(K_{\max }-K_{\min }\right)}{m}, K_{j}=K_{\min }+j \Delta K \text { for } j=0,1, \ldots, m
$$

and

$$
g_{t, t+\tau}^{i}\left(K_{j}\right)=\frac{C_{t, t+\tau}^{i}\left(K_{j}\right) / B(t, t+\tau)-\max \left(S_{t}^{i} / B(t, t+\tau)-K_{j}, 0\right)}{K_{j}^{2}}
$$

For each time-to-maturity $\tau$ from six to 60 days, we calculate the model-free implied variance each day for each underlying asset that has at least three available options outstanding, using all the available options at time $t .{ }^{5}$ For the risk-free rate, we use the Tbill rate of appropriate maturity (interpolated when necessary) from OptionMetrics, namely, the zero-coupon curve. For the dividend rate for the index, we employ the daily data on the index dividend yield from OptionMetrics. To infer the continuously compounded dividend rate for each individual asset, we combine the forward price with the spot rate used for the forward price calculations. We obtain the mean continuously compounded dividend rate by averaging the implied OptionMetrics dividends. Finally, we annualize the model-free implied variance using 252 trading days in a calendar day.

The specific implementation follows the approach of Jiang and Tian (2005). It is well known that options are traded only over a limited number of strikes. In principle, expression (12) requires the prices of options with strikes $K_{j}$ for $j=0,1, \ldots, m$. However, the corresponding option prices are not observable because these options are not listed. We apply the curve-fitting method to the Black and Scholes implied volatilities instead of

\footnotetext{
${ }^{5}$ The window from six days to 60 days corresponds to the maximum range of time to maturity we allow in the necessary interpolation to have enough options every day in the sample with 30 days to maturity.
} 
applying the method to option prices. The prices of listed calls (and puts with different strikes) are first transformed into implied volatilities using the Black and Scholes model and a smooth function is fitted to the implied volatilities using cubic splines. ${ }^{6}$ Then, we extract implied volatilities at strikes $K_{j}$ from the fitted function. Finally, we employ Eq. (12) to calculate the model-free implied variance using the extracted option prices.

The range of available strikes sometimes is not sufficiently large. For option prices outside the range between the maximum and minimum available strikes, we also follow Jiang and Tian (2005) and use the endpoint implied volatility to extrapolate their option prices. This implies that the volatility function is assumed to be constant beyond the maximum and minimum strikes. ${ }^{7}$ Finally, discretization errors are unlikely to have any effect on the model-free implied variance if a sufficiently large $m$, beyond 20 , is chosen. In our case, we employ an $m$ that equals one hundred.

At each time $t$, we focus on a $\tau=30$-day horizon maturity, interpolated when necessary using the nearest maturities $\tau_{1}$ and $\tau_{2}$ following the procedure of Carr and $\mathrm{Wu}$ (2009). The interpolation is linear in total variance:

$M F I V_{t, t+\tau}^{i}=\frac{1}{\tau}\left[\frac{M F I V_{t, t+\tau_{1}}^{i} \tau_{1}\left(\tau_{2}-\tau\right)+M F I V_{t, t+\tau_{2}}^{i} \tau_{2}\left(\tau-\tau_{1}\right)}{\left(\tau_{2}-\tau_{1}\right)}\right]$

We use the square root of the model-free implied variance to approximate the model-free annualized implied volatility as

$$
\operatorname{MFIVOL}_{t, t+\tau}^{i}=\sqrt{M F I V_{t, t+\tau}^{i}} \text {. }
$$

\footnotetext{
${ }^{6}$ As pointed out by Jiang and Tian (2005), the curve-fitting procedure does not assume that the Black and Scholes model holds. It is a tool to provide a one-to-one mapping between prices and implied volatilities.

${ }^{7}$ Jiang and Tian (2005) discuss this approximation error and the (different) truncation error that arise when the tails of the distribution across strikes are ignored. In our case and to avoid the truncation error, we use 3.5 standard deviations from the spot underlying price as truncation points.
} 
For each day in the sample period, we also calculate the realized variance over the same period as that for which implied variance is obtained for that day, that is, for 30 days, requiring that no more than 14 returns be missing from the sample:

$$
R V_{t, t+\tau}^{i}=\frac{1}{\tau} \sum_{s=1}^{\tau} R_{t+s}^{2}
$$

where $R$ denotes the rate of return adjusted by dividends and splits. As before, we annualized the realized variance and take the square root to obtain the realized volatility:

$$
R V O L_{t, t+\tau}^{i}=\sqrt{R V_{t, t+\tau}^{i}}
$$

Given that we always employ the same horizon in the analysis, we refer to this horizon as $t$ +1 corresponding to the maturity date with the fixed chosen maturity that we use for the rest of the paper. Hence, for each asset and the index, we calculate the volatility risk premium, $V R P$, at the 30-day horizon as the difference between the corresponding realized and model-free implied volatility:

$$
V R P_{t, t+1}^{i}=R \operatorname{VOL}_{t, t+1}^{i}-\text { MFIVOL }_{t, t+1}^{i} .
$$

We next construct $20 V R P$ beta-sorted portfolios using the following procedure. We estimate rolling VRP betas for each month using daily data over the previous month on the individual $V R P$ and the market $V R P$. Each month, we rank all VRP betas and construct 20 equally weighted VRP beta-sorted portfolios. Portfolio 1 contains the volatility risk premium securities with the most negative VRP betas, and Portfolio 20 includes the most positive ones. The components of all portfolios are updated every month during the sample period. All portfolios have approximately the same number of securities, with an average of 5.3 securities per portfolio, and the asset must have at least 15 daily observations to be included in the portfolios. 
Fig. 1 displays the behavior of Portfolios 1, 10, and 20 sorted by $V R P$ beta, as well as the market $V R P$. We display the $V R P$ of the market using options written on the $\mathrm{S} \& \mathrm{P} 100$ Index, so that the series contained in Fig. 1 is not the cross-sectional average of the individual VRP. For the Portfolios $\mathrm{P} 10 \mathrm{~B}$ and $\mathrm{P} 20 \mathrm{~B}$ and the market, the positive peaks coincide with periods of high realized volatility. Portfolio $\mathrm{P} 1 \mathrm{~B}$ tends to have a positive $V R P$ even during normal economic times, and Portfolio P20B presents a negative VRP during normal and expansion months and a positive $V R P$ during bad economic times. As expected, given the positive and high average level of the VRP beta of Portfolio P20B, its behavior closely follows the market $V R P$, but with more extreme peaks. In any case, this figure suggests that the ranking procedure generates sufficiently different cross-sectional behavior to justify the analysis of the cross-sectional empirical results under this sorting characteristic. ${ }^{8}$

\section{[INSERT FIGURE 1 AROUND HERE]}

\section{Volatility risk premium characteristics at the portfolio level}

This paper's main contribution is to explain why the volatility risk premia are different across assets. Our cross-sectional analysis employs 20 VRP beta-sorted portfolios. Before discussing the determinants of the cross-sectional variation of volatility risk premia, we report in Table 1 the basic characteristics of our 20 VRP beta-sorted portfolios. The average volatility risk premia are $10.3 \%$ and $-3.4 \%$ for Portfolios $\mathrm{P} 1 \mathrm{~B}$ and $\mathrm{P} 20 \mathrm{~B}$, respectively. All of these figures are in annualized terms. As expected, given the wellknown evidence provided by, among others, Bakshi and Madan (2006) and Carr and Wu

\footnotetext{
${ }^{8} \mathrm{We}$ also construct an alternative set of 20 portfolios based on the VRP level. Using the VRP on the last day of the previous month, we rank all VRP values from the lowest (more negative) to the highest. Portfolio 1 contains the assets with the lowest VRP, and Portfolio 20 has securities with the highest VRP. Our main empirical results and conclusions are checked employing this alternative ranking to analyze the robustness of our results.
} 
(2009), the market $V R P$ is, on average, negative and equal to $-1.4 \%$. The average annualized $V R P$ obtained directly from daily data present a very similar pattern, ranging from $10.1 \%$ to $-4.5 \%$. The magnitude of the $V R P$ cross-sectional differences is large and seems to justify the study of their determinants. These averages indicate that investors can have very different volatility investment vehicles, depending on whether they go long or short on volatility. We tend to identify the purchase of volatility as a hedging instrument against potentially large stock market declines. The evidence reported in Table 1 suggests that, on average, going long on volatility can also lead to substantial gains, depending on the portfolio for which investors buy volatility. ${ }^{9}$ The standard deviations of the VRP values of these portfolios suggest that portfolios with a higher average $V R P$ and, especially, those with a more negative average $V R P$ are the most volatile portfolios in terms of $V R P$ payoffs. Fig. 1 also reflects the highly volatile behavior of the VRP of $\mathrm{P} 20 \mathrm{~B}$, followed by the relatively smoother behavior of $\mathrm{P} 1 \mathrm{~B}$. The patterns and the dispersion of the unconditional moments of the $V R P$ across portfolios call for a better grasp of volatility risk premia at the cross section.

\section{[INSERT TABLE 1 AROUND HERE]}

The fifth column of Table 1 reports the VRP betas of each of the portfolios relative to the VRP of the market index. Using monthly data from January 1996 to February 2011, we estimate a market model type of ordinary least squares (OLS) regression of the following form:

$$
V R P_{t, t+1}^{p}=a+\beta V R P_{t, t+1}^{m}+\varepsilon_{t, t+1}
$$

\footnotetext{
9 As discussed by Carr and Lee $(2007,2009)$, due to the concavity's price impact associated with Jensen's inequality, the difference between the value of a variance swap and the value of a volatility swap depends on the volatility of the volatility of the underlying asset. If we recognize this potential bias and adjust our estimated volatility risk premia accordingly, the dispersion between the volatility risk premia across portfolios remains. See Burashi, Trojani, and Vedolin (2014) for a similar approximation.
} 
where $V R P_{t, t+1}^{p}$ is the volatility risk premium of each of the 20 portfolios and $V R P_{t, t+1}^{m}$ is the volatility risk premium of the market index. The VRP betas reflect the construction criterion, with unconditional VRP betas of -0.95 for $\mathrm{P} 1 \mathrm{~B}$ and 3.89 for $\mathrm{P} 20 \mathrm{~B}$. As in the case of average volatility risk premia, the cross-sectional differences in VRP betas are large. ${ }^{10}$

Given that, for each month during the sample period, we can identify the underlying components of the 20 portfolios, we calculate the portfolio returns of the $20 \mathrm{VRP}$ betasorted portfolios. In Table 1, we also display the market betas of the 20 portfolios with respect to the US market portfolio index and the S\&P 100 Index. As with the standard deviation, the cross-sectional behavior of market betas presents a U-shaped pattern, with market betas being especially high for portfolios with a more negative average VRP. Portfolio P20B has the highest return beta, with a value as high as 1.52 when measured relative to the $\mathrm{S} \& \mathrm{P} 100$ Index return.

Fig. 2 displays the rolling volatility risk premium betas and market return betas for the extreme and intermediate portfolios from the set of $20 \mathrm{VRP}$ beta-sorted portfolios. The rolling estimation employs 60 past monthly observations in all cases. As expected, a direct comparison of Panels A and B of Fig. 2 shows that the volatility betas are more stable over time than the market betas are. This is true for all displayed portfolios. However, around the fall of 2008, a big positive jump is evident in the volatility betas of all five portfolios. Moreover, from that time onward, the cross-sectional differences in volatility betas across the five portfolios tend to decrease relative to the period before the financial crisis. The volatility sensitivity with respect to the market volatility risk premium becomes more

\footnotetext{
10 Table A1 in the Appendix reports the same descriptive statistics when we adjust for the mean in the estimation of the realized volatility and, therefore, in the estimation of the volatility risk premia. This follows the estimation by Bakshi and Madan (2006). Appendix Section A.1 also contains a brief discussion about the results.
} 
similar across portfolios after the crisis. After the jump, the volatility betas of Portfolios P19B and P20B remain at the same level they were at before the jump occurred, but the volatility betas of Portfolios P1B and P2B remain at the same level they were at the peak of the jump. Meanwhile, return betas are clearly more volatile. The market beta of Portfolio P1B remains relatively low before the crisis but then starts rising until the beginning of 2008. What is more interesting is that the return beta of Portfolio P1B starts dropping dramatically just before the peak of the crisis in the fall of 2008. Portfolio P20B shows the opposite behavior. Its market beta experiences an extremely high jump around the peak of the crisis.

\section{[INSERT FIGURE 2 AROUND HERE]}

Finally, the last column of Table 1 contains the average relative bid-ask spread of the options associated with the components of the 20 portfolios. The options traded on the components of portfolios with positive and high average $V R P$ values can be extremely illiquid. If this is the case, the replicating strategy employed to obtain synthetic variance swaps associated with illiquid options can be more costly than in other cases. However, the average bid-ask spreads reflect precisely the opposite. The Portfolio P1B contains, on average, the most liquid options, and P20B presents the highest relative bid-ask spread across the 20 portfolios. Therefore, on average, market return betas and bid-ask spreads are higher for the two portfolios with the highest $V R P$ betas.

Table 2 contains the correlation coefficients between representative portfolios sorted by $V R P$ betas and the market VRP. Panel A employs monthly data, and Panel B displays the results with daily data. As expected, given its highly negative VRP beta, Portfolio P1B's correlation with the rest of the portfolios becomes increasingly negative. Not surprisingly, the correlation of these portfolios with the market $V R P$ displays an 
increasingly monotonic relation, going from a negative correlation of -0.366 for P1B to a positive correlation of 0.863 for $\mathrm{P} 20 \mathrm{~B}$. A similar pattern is found when using daily data. ${ }^{11}$

\section{[INSERT TABLE 2 AROUND HERE]}

Panels $\mathrm{A}$ and $\mathrm{B}$ of Table 3 contain the full-sample $V R P$ betas for five representative $V R P$ beta-sorted portfolios, controlling for well-known aggregate risk factors. The robustness of the magnitudes of the $V R P$ betas, reported again in the first column of Table 3, is clear across all portfolios. Independently of the factors employed in the regressions, Portfolio P1B has a negative beta, and P20B has a very high but positive volatility risk premium beta. In all cases, we employ standard errors robust to heteroskedasticityautocorrelation (HAC). The relation between the $V R P$ betas and the average volatility risk premia of all portfolios is maintained across all aggregate factors. We can conclude that, for $V R P$ beta-sorted portfolios, the volatility risk premia are especially explained by the market $V R P$, the excess market return, the default premium, and consumption growth. However, $V R P$ betas do not seem to be significantly different from zero when stockholder consumption growth is used. Overall, we conclude that the unconditional betas of these state variables are, in most cases, statistically different from zero, even when we employ all three explanatory variables simultaneously.

\section{[INSERT TABLE 3 AROUND HERE]}

\section{Cross-sectional variation of portfolio volatility risk premia}

We tests all SDF specifications discussed in Section 2 using the two-pass crosssectional regression approach of Fama and MacBeth (1973). In addition, we test all models using a generalized method of moments (GMM) framework with the same weighting

\footnotetext{
11 The correlation coefficients for the financial and macroeconomic indicators employed in the paper are reported in Table A2 in the Appendix.
} 
matrix across all test portfolios to compare the performance of the models by the Hansen and Jagannathan (1997) distance. To save space and given that the main empirical results are very similar, we report only the empirical results from the traditional two-pass crosssectional approach. ${ }^{12}$

\subsection{Two-pass cross-sectional estimation and tests}

We next describe the econometric strategy for testing the competing asset pricing models of the determinants of the cross section of volatility risk premia using the models' beta specifications. We test the linear specifications using our 20 VRP beta-sorted portfolios. In all cases, $\lambda_{0}$ is the zero-beta rate and $\lambda_{k}$ for $k=1, \ldots, K$ are the risk premia associated with the $K$ aggregate risk factors that drive the cross-sectional variation among volatility swap payoffs for our set of 20 portfolios, $p=1, \ldots, 20$, as follows.

Model 1. Recursive preferences with either market wealth or market volatility risk premium as the non-observable continuation value:

$E\left(V R P_{t, t+1}^{p}\right)=\lambda_{0}+\lambda_{c} \beta_{c}^{p}+\lambda_{m} \beta_{m}^{p}$

and

$$
E\left(V R P_{t, t+1}^{p}\right)=\lambda_{0}+\lambda_{c} \beta_{c}^{p}+\lambda_{v r p}^{m} \beta_{m v r p}^{p}
$$

where $c$ represents either the aggregate consumption growth of nondurable goods and services or stockholder consumption growth.

Model 2. The Bakshi and Madan (2006) model with higher-order moments:

$$
E\left(V R P_{t, t+1}^{p}\right)=\lambda_{0}+\lambda_{m} \beta_{m}^{p}+\lambda_{s k k u} \beta_{m^{2}}^{p}
$$

\footnotetext{
12 The results using the GMM estimation procedure are available upon request.
} 
Model 3. The CAPM-type approach with the market volatility risk premium as the only risk factor:

$$
E\left(V R P_{t, t+1}^{p}\right)=\lambda_{0}+\lambda_{v r p}^{m} \beta_{m v r p}^{p}
$$

Model 4. A two-factor model with the market volatility risk premium and the default premium:

$$
E\left(V R P_{t, t+1}^{p}\right)=\lambda_{0}+\lambda_{v r p}^{m} \beta_{m v r p}^{p}+\lambda_{d e f} \beta_{d e f}^{p} .
$$

Model 5. A four-factor model with the market volatility risk premium, the default premium, the high minus low (HML) Fama and French factor, and market wealth:

$$
E\left(V R P_{t, t+1}^{p}\right)=\lambda_{0}+\lambda_{v r p}^{m} \beta_{m v r p}^{p}+\lambda_{d e f} \beta_{d e f}^{p}+\lambda_{h m l} \beta_{h m l}^{p}+\lambda_{m} \beta_{m}^{p} .^{13}
$$

Therefore, we test the linear versions of the models using the alternative $K$-factor beta specifications in which the volatility risk premia are linear in the volatility risk premium betas, that is, $E(V R P)=X \lambda$, where $X=\left[1_{N}, \beta\right]$ and $\lambda=\left[\lambda_{0}, \lambda_{1}^{\prime}\right]^{\prime}$ is a vector consisting of the zero-beta rate, $\lambda_{0}$, and the risk premia on the $K$ factors, $\lambda_{1}$. The pricing errors of the $N$ portfolios are given by $e=E(V R P)-X \lambda$

As a goodness of fit measure of the competing models, we employ the crosssectional $R^{2}$ defined by Kan, Robotti, and Shanken (2013, KRS hereafter) as

$$
R^{2}=1-\frac{Q}{Q_{0}},
$$

where the $Q$ statistic, given by

\footnotetext{
${ }^{13}$ In our empirical strategy, we include several specifications based on the Fama and French (1993) threefactor model and the four-factor model with momentum as suggested by Carhart (1997). The results show that neither the size nor the momentum factors explain the cross-sectional variation of volatility risk premia. The empirical results are available upon request.
} 
$Q=e^{\prime} V^{-1} e=E(V R P)^{\prime} V^{-1} E(V R P)-E(V R P)^{\prime} V^{-1} X\left(X^{\prime} V^{-1} X\right)^{-1} X^{\prime} V^{-1} E(V R P)$,

represents the aggregate pricing errors and $Q_{0}=e_{0}^{\prime} V^{-1} e_{0}$ denotes the deviations of the mean returns from their cross-sectional average, with

$e_{0}=\left\lfloor I_{N}-1_{N}\left(1_{N}^{\prime} V^{-1} 1_{N}\right)^{-1} 1_{N}^{\prime} V^{-1}\right\rfloor E(V R P)$

and $V$ is the variance-covariance matrix of the portfolio volatility risk premia. As KRS point out, the $R^{2}$ statistic given by Eq. (28) is a relative measure of the goodness of fit as it compares the magnitude of the model's expected return deviations with that of typical deviations from the average expected return. Moreover, $0 \leq R^{2} \leq 1$ and $R^{2}$ is a decreasing function of the aggregate pricing errors $Q$. Thus, $R^{2}$ given by Eq. (28) is a reasonable and well-defined measure of goodness of fit. In fact, we employ $R^{2}$ for average returns instead of the average of monthly $R^{2}$ values.

In addition, KRS show how to perform a test of whether the model has any explanatory power for pricing assets cross-sectionally. In other words, they test whether the null hypothesis of $R^{2}=0$ can be rejected. The asymptotic test is given by

$T R^{2}=\stackrel{\mathrm{A}}{\rightarrow} \sum_{i=1}^{K} \frac{\xi_{i}}{Q_{0}} x_{i}$

where the $x_{i}$ 's are independent $\chi^{2}(1)$ random variables and the $\xi_{i}$ 's are the $K$ nonzero eigenvalues of

$\left\lfloor\beta^{\prime} V^{-1} \beta-\beta^{\prime} V^{-1} 1_{N}\left(1_{N}^{\prime} V^{-1} 1_{N}\right)^{-1} 1_{N}^{\prime} V^{-1} \beta\right\rfloor \operatorname{Var}\left(\hat{\lambda}_{1}\right)$, 
where $\operatorname{Var}\left(\hat{\lambda}_{1}\right)$ is the expression adjusted by errors-in-variable and misspecification of the model. ${ }^{14}$ The asymptotic distribution of $\hat{\lambda}$ under the misspecified models is

$$
\sqrt{T}(\hat{\lambda}-\lambda) \stackrel{A}{\rightarrow} N\left(0_{K+1}, \operatorname{Var}(\hat{\lambda})\right)
$$

where $\operatorname{Var}(\hat{\lambda})=\sum_{\tau=-\infty}^{\infty} E\left(v_{t} v_{t-\tau}^{\prime}\right)$ and

$$
v_{t}=\underbrace{\left(\lambda_{t}-\lambda\right)}_{\text {variance when true betas }}-\underbrace{\left(\eta_{t}-\eta\right) \omega_{t}}_{\text {errors-in-variables adjustment }}+\underbrace{H z_{t} u_{t}}_{\text {misspecificationterm }}
$$

with

$$
\begin{aligned}
& \eta_{t}=\left[\lambda_{0, t},\left(\lambda_{1, t}-f_{t}\right)^{\prime}\right]^{\prime} ; \eta=\left[\lambda_{0},\left(\lambda_{1}-f\right)^{\prime}\right]^{\prime} ; \mathrm{u}_{\mathrm{t}}=e^{\prime} V^{-1}\left(V R P_{t}-E(V R P)\right) \\
& \omega_{t}=\lambda_{1}^{\prime} \Omega^{-1}\left(f_{t}-f\right) ; z_{t}=\left[0,\left(f_{t}-f\right)^{\prime} \Omega^{-1}\right]^{\prime},
\end{aligned}
$$

and

$$
H=\left(X^{\prime} V^{-1} X\right)^{-1}
$$

where $\Omega$ is the variance-covariance matrix of the factors denoted by $f_{t}$.

Finally, we present the test for comparing two competing models. Suppose $M_{1} \neq M_{2}$ and $0<R_{1}^{2}=R_{2}^{2}<1$. Then

$$
\sqrt{T}\left(\hat{R}_{1}^{2}-\hat{R}_{2}^{2}\right) \stackrel{A}{\rightarrow} N\left(0, \sum_{\tau=-\infty}^{\infty} E\left(d_{t} d_{t-\tau}\right)\right)
$$

where

$$
d_{t}=Q_{0}^{-1}\left(u_{1 t}^{2}-2 u_{1 t} M_{1 t}-u_{2 t}^{2}+2 u_{2 t} M_{2 t}\right)
$$

and

${ }^{14}$ The $p$-values to test the null hypothesis $R^{2}=0$ are calculated using the procedure first proposed by Jagannathan and Wang (1996). 


$$
u_{1 t}=e_{1}^{\prime} V^{-1}\left(V R P_{t}-E(V R P)\right) \text { and } u_{2 t}=e_{2}^{\prime} V^{-1}\left(V R P_{t}-E(V R P)\right)
$$

\subsection{Two-pass cross-sectional empirical results}

Panel A of Table 4 contains the results of the two-pass cross-sectional regressions using consumption-based factors, and Panel B displays the results concerning factor-based models.

\section{[INSERT TABLE 4 AROUND HERE]}

In all cases, we adapt the testing framework to the Fama and MacBeth (1973) twopass cross-sectional methodology, in which we estimate rolling betas using the first 60 months of the sample as a fixed estimation period and then use a rolling window of 59 months of past data plus the month in which we perform the cross-sectional regression with the 20 portfolios. Hence, for each month $t$, we always employ a beta estimated with 60 observations. Moreover, below all risk premia estimators, we report in parentheses the $p$ values associated with the traditional Fama and MacBeth standard error and in brackets the $p$-values for the standard error adjusted for errors in variables and the potential misspecification of the model as captured by expression (34). We also provide two measures of goodness of fit. We report the mean absolute pricing error $(M A E)$, calculated as

$$
M A E=\frac{1}{20} \sum_{p=1}^{20}\left|\overline{\hat{e}}_{p}\right|
$$

where $\overline{\hat{e}}_{p}$ is the mean pricing error associated with each of the 20 portfolios. The last column of Table 4 reports the $\hat{R}^{2}$ value given by Eq. (28), where in parentheses we display 
the $p$-value for the test of the null hypothesis given by $R^{2}=0$ from expression (31) and in brackets we report the standard error of $\hat{R}^{2}$ under the assumption that $0 \leq R^{2} \leq 1$.

Regarding consumption models, the results suggest that the standard errors of the risk premia estimators are very sensitive to potential model misspecification. The risk premia associated with consumption growth, either aggregate consumption or stockholder consumption, are not statistically different from zero. Consumption risk does not seem to be priced in the cross section of the volatility risk premia. The only statistically significant risk premia are the market portfolio return in the case of the recursive preference model with aggregate consumption growth and that related to the market volatility risk premium when we approximate the continuation value with volatility swaps instead of with the market portfolio return. As theory suggests, the sign of the statistically significant risk premium associated with market wealth is positive and it becomes negative when the market VRP under recursive preferences is employed. Two additional results of Panel A of Table 4 are relevant. First, the $M A E$ values reported in Panel A tend to be higher than those of Panel B. Second, for all models, we cannot reject the null hypothesis that $R^{2}$ is statistically equal to zero, because the standard errors of the $\hat{R}^{2}$ values suggest that all models are estimated with a great deal of noise. ${ }^{15}$

Panel B of Table 4 shows that factor-based models explain the cross section of volatility risk premia much more accurately. In two cases, the asset pricing specification is not statistically rejected. These models always include the market $V R P$ and the default premium. They are also the models with a lower $M A E$. It is also true that although the

\footnotetext{
15 Consumption-based models with either power or external habit preferences of Campbell and Cochrane (1999) do not help explain the cross-sectional variation of volatility risk premia. We reject all alternative specifications, and the associated risk premia are not statistically different from zero. The specific empirical results are available upon request.
} 
model with HML and the excess market returns as additional factors is not rejected, the coefficients associated with either the excess market return or the HML factor are not statistically different from zero. However, in both cases, the market volatility risk premium beta is significantly priced, with the expected negative sign. ${ }^{16}$ Again, in both cases, the default risk premium beta is positive and statistically different from zero. Hence, controlling for the market volatility risk premium betas, the higher the default beta is, the higher the average payoff expected from volatility swaps in the cross section. Therefore, we find that, on average, both the market VRP and default risk are priced across portfolios. The two-factor model for volatility risk generates statistically significant risk premia of $-0.6 \%$ and $1.2 \%$ for market volatility risk and default risk, respectively. The $\hat{R}^{2}$ of the twofactor model is equal to 0.514 and is statistically different from zero, with a standard error of $0.211^{17}$

We also check the sensitivity of the risk premia estimators to the business cycle by dividing the full sample into two nonoverlapping subperiods. We first estimate the twofactor model from January 1996 to December 2006. The risk premia are $-0.6 \%$ and $0.6 \%$ for the market volatility beta and default beta, respectively. The $p$-values of the adjusted KRS standard errors are 0.014 and 0.001 for both risk premia estimators. The second subperiod that goes from January 2007 to February 2011 analyzes the years around the financial crisis. The risk premia are $-0.5 \%$ and $2.8 \%$ for the market volatility beta and default beta, respectively, with $p$-values of 0.564 and 0.018 for both risk premia estimators.

\footnotetext{
16 The negative sign reflects the fact that the market volatility risk premium tends to be positive for events of high marginal utility.

${ }^{17}$ Similar results are found when we estimate the two-pass cross-sectional regression using a constant beta throughout the sample period. Moreover, when we check all our empirical results using the alternative set of 20 portfolios ranked according to the level of the volatility risk premium, the results are qualitatively the same, independent of using consumption-based models or factor-based specifications. The two-factor model, with the market volatility risk premium and the default premium, exhibits a better competing performance than the rest of the models analyzed in our research. All empirical results are available upon request.
} 
The default risk premia beta remains significantly different from zero, and it increases during the Great Recession. The default beta risk is an important and key factor explaining the cross-sectional variation of volatility risk premia. ${ }^{18}$

The estimated risk premia associated with the market volatility beta are very consistent across all specifications. They move from $-0.7 \%$ to $-0.6 \%$ on a monthly basis and across models. The same result applies to the risk premia of default beta, which change only from $1.4 \%$ to $1.2 \%$ across alternative specifications. The risk premia of the market volatility beta is also stable and equal to $-0.7 \%$ in Panel A of Table 4 when either nondurable consumption or stockholder consumption is used in the recursive preference specification. This suggests that the risk premia of the two factor models are stable and robust across asset pricing models.

Fig. 3 displays the average realized $V R P$ against the fitted value for two representative asset pricing models. The two-factor model presents a better visual fit across all models and, in particular, it shows a better fit than the consumption-based model with recursive preferences. In any case, the difficulty of the theoretical two-factor model in explaining Portfolio P20B must be recognized. The model generates a negative payoff for this portfolio, which is too extreme (too highly negative) to obtain a more precise linear fit relative to actual data.

\section{[INSERT FIGURE 3 AROUND HERE]}

Finally, Table 5 reports the pairwise tests of equality of the two-pass cross-sectional regression $R^{2}$ values for alternative factor pricing models using the $20 V R P$ beta-sorted

\footnotetext{
${ }^{18}$ In Table A1 in the Appendix, we report the descriptive statistics of our 20 VRP beta-sorted portfolios when we adjust for the mean in the estimation of the volatility risk premia. The two-pass cross-sectional regression using these new estimates generates statistically significant risk premia associated with market volatility and the default betas. The estimated coefficients for the full sample period are $-0.7 \%$ and $1.1 \%$, respectively. As before, the results seem to be robust to alternative specifications.
} 
portfolios. It shows the results of the pairwise tests of equality of the two-pass crosssectional regression $R^{2}$ values for alternative factor pricing models. We report the difference between the sample cross-sectional $R^{2}$ values of the models in row $i$ and column

$j, \hat{R}_{i}^{2}-\hat{R}_{j}^{2}$, and the associated $p$-values in parentheses for the test of $\hat{R}_{i}^{2}=\hat{R}_{j}^{2}$. As before, these $p$-values allow for misspecifications of the models. The role of the default premium seems to be important for the cross-sectional pricing of volatility swaps, even under a statistical comparison of $R^{2}$ values. However, we cannot reject that the $\hat{R}^{2}$ values between the two-factor model and the model extended with the HML factor and excess market returns are equal. The two-factor model performs relatively well when compared with competing models. In any case, the results highlight the difficulty of distinguishing between the models from a statistical point of view. For example, the power of the test seems to be low when we compare the two-factor model with the consumption-based specifications using aggregate consumption growth. These models are estimated with a considerable amount of noise. We should not simply compare the point estimates of the $\hat{R}^{2}$ values. As KRS say, it seems reasonable to focus on individual $\hat{R}^{2}$ values instead of on differences across models.

\section{[INSERT TABLE 5 AROUND HERE]}

\section{Why does the default premium explain the cross-sectional variation of volatility risk} premia?

The default beta risk with respect to the volatility risk premia seems to be consistently priced in our cross section. We next provide an intuitive but rigorous explanation of this finding. We employ the underlying components of the $20 \mathrm{VRP}$ beta-sorted portfolios to construct the corresponding 20 return portfolios. We estimate OLS regressions with HAC- 
robust standard errors of the return of each portfolio on the market return and the default premium. The first column of Table 6 reports the default return betas for a set of representative portfolios, which include the five portfolios with negative and the lowest $V R P$ betas $(\mathrm{P} 1 \mathrm{~B} / \mathrm{P} 5 \mathrm{~B})$, the intermediate portfolio $(\mathrm{P} 10 \mathrm{~B})$, and the five portfolios with the highest positive $V R P$ betas (P16B/P20B). Similarly, the second column reports the financial stress return beta, controlling, as before, for the market return, but now with respect to the St. Louis Fed Financial Stress Index (STLFSI). The STLFSI measures the degree of financial stress in the market and is constructed from 18 series: seven interest rate series, six yield spreads, and five other indicators. Each of these variables captures some aspect of financial stress. In this regard, it is a broader measure of financial credit risk or financial stress than the default premium. As was learned from the Great Recession, financial stress can arise from dimensions other than the default spread. The serious difficulties of financial institutions in providing funding, especially to finance short-term liabilities, encourage the use of financial stress indicators that also employ funding liquidity-related aspects of the economic situation. Therefore, our idea is to complement the evidence associated with the default premium with another closely related index to further motivate the importance of financial or credit stress as the ultimate reason behind the cross-sectional differences of volatility risk premia. By construction, the average value of the index is equal to zero. Thus, zero reflects normal financial market conditions. Values below zero suggest belowaverage financial stress, and values above zero indicate above-average financial stress. ${ }^{19}$ Increasing values of this index can, therefore, be interpreted in the same way as increasing the values of the default premium. Both reflect dire financial situations. In fact, the

\footnotetext{
${ }^{19}$ For further details, see http://www.stlouisfed.org/newsroom/financial-stress-index/.
} 
correlation coefficient between the default premium and the STLFSI is 0.84 during our sample period.

\section{[INSERT TABLE 6 AROUND HERE]}

The empirical results from the first two columns of Table 6 suggest a similar interpretation. The behavior of the components of Portfolios P1B through P5B is very different from the behavior of the underlying components of Portfolios P16B through P20B. The first portfolios have, on average, positive volatility risk premia, and the last portfolios have negative average volatility risk premia. Using either the default premium or the STLFSI, the relation between the returns of the first five portfolios and financial stress is positive. When default or the financial stress index increases, the returns of these portfolios increase. These portfolios seem to be good hedgers relative to financial stress. However, Portfolios P16B through P20B are negative and significantly correlated with respect to financial stress. Even when the market return is controlled for, when measures of financial stress increase, their return significantly decreases.

To further illustrate the different behavior of both sets of extreme portfolios, we regress the returns of the portfolios on the market return and on an interaction term defined as the product between either the default premium or the financial stress indicator and a dummy variable that takes the value of one for a bad economic state and zero otherwise:

$$
R_{p, t+1}=a+\beta R_{m, t+1}+\delta F S I_{t+1} \times D_{t+1}+\varepsilon_{t, t+1}
$$

where FSI is either the default premium or the STLFSI. As a way of measuring the economic situation, we employ two economic state indicators of the US economy. We first employ the National Bureau of Economic Research (NBER) recession official dates, and we complement this measure with the Leading Index for the US economy (USSLIND), 
which is a forward-looking indicator also provided by the Federal Reserve Bank of St. Louis. This is a monthly seasonally adjusted index that includes variables recognized to be economic variables that lead the economy. The index includes housing permits, unemployment insurance claims, the interest rate spread between the ten-year Treasury bond and the three-month Treasury bill, and delivery times from the Institute for Supply Management's Manufacturing Business Survey. ${ }^{20}$ This index takes either positive or negative values. Our dummy variable equals one when the USLIND takes a negative value and zero otherwise. The coefficient associated with the interaction term shows how important financial stress is for these portfolios during bad economic states. We expect a positive and significant coefficient for Portfolios P1B through P5B and a negative and significant coefficient for Portfolios P16B through P20B. The results reported in the third to sixth columns for the default and financial stress betas are consistent with our conjecture. The impact of financial and credit stress episodes during bad economic times affect alternative portfolios completely differently, depending upon the average level (and average volatility beta) of their volatility risk premia.

Overall, these results suggest that investors can rationally hedge the credit and financial stress risk of these components by buying volatility swaps. For those assets negatively affected by financial stress, they are willing to pay a high volatility swap to cover that credit and financial risk stress. Therefore, on average, we can expect a negative payoff from holding long positions on volatility swaps associated with these assets and a positive average payoff from assets moving positively with default and financial stress risk. The behavior is expected to be more accentuated during bad economic states. This is exactly what we display in Table 6. It seems that the differences in the cross section of our

\footnotetext{
${ }^{20}$ For further details, see http://research.stlouisfed.org/fred2/series/USSLIND.
} 
$V R P$ beta-sorted portfolios reflect a very different behavior of these assets with respect to credit and financial stress.

To complete our argument, we should find evidence that the volatility risk premia of Portfolios P19B and P20B move positively with financial stress. In other words, the volatility payoff of these portfolios should cover increasing financial stress risk. This is again what we report in the last column of Table 6.

\section{Conclusions}

Most of the literature dealing with variance or volatility swaps is concerned with the variance risk premium at the market level. The empirical evidence shows that the market variance risk premium has very useful economic information content. Given this evidence, it is surprising how little research analyzes variance or volatility swaps at the individual or portfolio level. This paper discusses and tests the cross-sectional variation of the volatility risk premia for a set of 20 portfolios. We rank individual $V R P$ values by their betas with respect to the market volatility risk premium. Accordingly, we employ a set of $20 \mathrm{VRP}$ beta-sorted portfolios to analyze the determinants of their cross-sectional variation. We show that beta with respect to the market volatility risk premia and the default beta have statistically significant risk premia that help explain the cross-sectional variation of average volatility risk premia. This is especially the case for the default premium factor, and the empirical result holds even if we allow for potential misspecification of the models. Finally, we relate our findings to credit and financial stress risk. We show that the success of the default premium in the cross-sectional variation of the volatility risk premia seems to be explained by the very different behavior that the underlying components of our $20 \mathrm{VRP}$ betas-sorted portfolios have with respect to financial stress risk. 


\section{Appendix}

We provide an additional analysis in which we estimate the realized variance adjusting for the mean portfolio returns, and show the correlation coefficients between the state variables employed in the empirical tests.

A.1. Descriptive statistics and betas: portfolios sorted by volatility risk premium betas when the volatility risk premium estimates are adjusted by the mean

When we estimate the realized variance for each asset in our sample, we employ the following equation:

$$
R V_{t, t+\tau}^{i}=\frac{1}{\tau} \sum_{s=1}^{\tau} R_{t+s}^{2}
$$

When using daily data, this seems to be reasonable because the mean return is generally negligible. As Bakshi and Madan (2006) do, we can also estimate the realized variance adjusted for the mean return during the corresponding horizon:

$$
R V_{t, t+\tau}^{i}=\frac{1}{\tau} \sum_{s=1}^{\tau}\left(R_{t+s}^{2}-\bar{R}_{\tau}\right)
$$

Table A1 contains the descriptive statistics and betas of the 20 VRP beta-sorted portfolios.

Overall, the results are very similar with respect to Table 1 . However, the average volatility risk premia of negative volatility beta portfolios and portfolios with low volatility betas (PB1/PB6) tend to be slightly lower. Portfolios with high positive volatility betas (P15B/P20B) show a more negative average volatility risk premia. Also, when we adjust for the mean, the average cross-sectional dispersion of volatility betas across portfolios goes from -0.88 to 3.81 , where in Table 1 the range moves from -0.95 to 3.89 . Therefore, the average dispersion is slightly reduced when we adjust for the mean in the realized 
variance. Finally, the magnitudes of the market return betas are similar in both tables across portfolios.

\section{[INSERT TABLE A1 AROUND HERE]}

\section{A.2. Correlation coefficients between state variables, January 1996 to February 2011}

Table A2 reports the correlation between the market VRP and several macroeconomic and financial indicators. The correlation between the excess market return and the market $V R P$ is negative and equals -0.273 . This is well known and implies a negative correlation between market returns and realized market volatilities. Thus, going long on the market volatility swap provides a hedging investment vehicle for moments of extremely high market volatility. However, the compensation for this hedging strategy is, on average, negative. The results also show a negative correlation of the market $V R P$ with consumption growth, although the correlation is more negative for aggregate consumption than for stockholder consumption. The correlation with the HML and momentum factors is positive, and the correlation with the default premium is also positive and equals 0.075 . As expected, the correlation between the default premium and either the excess market return or consumption growth is negative, being especially negative with respect to aggregate consumption growth.

[INSERT TABLE A2 AROUND HERE] 


\section{References}

Bakshi, G., Cao, C., Chen, Z., 1997. Empirical performance of alternative option pricing models. Journal of Finance 52, 2003-2049.

Bakshi, G., Kapadia, N., 2003a. Delta-hedged gains and the negative volatility risk premium. Review of Financial Studies 16, 527-566.

Bakshi, G., Kapadia, N., 2003b. Volatility risk premium embedded in individual equity options: some new insights. Journal of Derivatives 11, 45-54.

Bakshi, G., Madan, D., 2006. A theory of volatility spreads. Management Science 52, 1945-1956.

Bali, T., Zhou, H., 2015. Risk, uncertainty, and expected returns. Journal of Financial and Quantitative Analysis, forthcoming.

Bekaert, G., Hoerova, M., 2013. The VIX, the variance premium and stock market volatility. Unpublished working paper. European Central Bank, Frankfurt, Germany.

Bekaert, G., Hoerova, M., Lo Duca, M., 2013. Risk, uncertainty, and monetary policy. Journal of Monetary Economics 60, 771-788.

Bollerslev, T., Gibson, M., Zhou, H., 2011. Dynamic estimation of volatility risk premia and investor risk aversion from option-implied and realized volatilities. Journal of Econometrics 160, 102-118.

Bollerslev, T., Tauchen, G., Zhou, H., 2009. Expected returns and variance risk premia. Review of Financial Studies 22, 4463-4492.

Britten-Jones, M., Neuberger, A., 2000. Option prices, implied price processes, and stochastic volatility. Journal of Finance 55, 839-866. 
Buraschi, A., Trojani, F., Vedolin, A., 2014. When uncertainty blows in the orchard: comovements and equilibrium volatility risk premia. Journal of Finance 69, 101-137.

Campbell, J., Cochrane, J., 1999. By force of habit: a consumption-based explanation of aggregate stock market behavior. Journal of Political Economy 107, 205-251.

Campbell, J., Giglio, S., Polk, C., Turley, R., 2014. An intertemporal CAPM with stochastic volatility. Unpublished working paper. Harvard University, Cambridge, MA.

Carhart, M., 1997. On persistence in mutual fund performance. Journal of Finance 52, $57-82$.

Carr, P., Lee, R., 2007. Realized volatility and variance: options via swaps. Risk 5, 76-83.

Carr, P., Lee, R., 2009. Volatility derivatives. Annual Review of Financial Economics 1, $1-21$.

Carr, P., Wu, L., 2009. Variance risk premiums. Review of Financial Studies 22, $1311-1341$.

Chabi-Yo, F., 2012. Pricing kernels with stochastic skewness and volatility risk. Management Science 58, 624-640.

Drechsler, I., Yaron, A., 2011. What's vol got to do with it? Review of Financial Studies $24,1-45$.

Driessen, J., Maenhout, P., Vilkov, G., 2009. The price of correlation risk: evidence from equity options. Journal of Finance 64, 1377-1406.

Epstein, L., Zin, S., 1991. Substitution, risk aversion, and the temporal behavior of consumption and asset returns: an empirical investigation. Journal of Political Economy $99,555-576$.

Fama, E., French, K., 1993. Common risk factors in the returns on stocks and bonds. Journal of Financial Economics 33, 3-56. 
Fama, E., Mac-Beth, J., 1973. Risk, return, and equilibrium: empirical tests. Journal of Political Economy 81, 607-636.

Hansen, L., Jagannathan, R., 1997. Assessing specification errors in stochastic discount factor models. Journal of Finance 52, 557-590.

Harvey, C., Liu, Y., Zhu, H., 2014. ... and the cross section of expected returns. Unpublished working paper. Duke University, Durham, NC.

Jagannathan, R., Wang, Z., 1996. The conditional CAPM and the cross section of expected returns. Journal of Finance 51, 3-54.

Jiang, G., Tian, Y., 2005. The model free implied volatility and its information content. Review of Financial Studies 18, 1305-1342.

Kan, R., Robotti, C., Shanken, J., 2013. Pricing model performance and the two-pass crosssectional regression methodology. Journal of Finance 68, 2617-2649.

Lewellen, J., Nagel, S., Shanken, J., 2010. A skeptical appraisal of asset pricing tests. Journal of Financial Economics 96, 175-194.

Malloy, C., Moskowitz, T., Vissing-Jorgensen, A., 2011. Long-run stockholder consumption risk and asset returns. Journal of Finance 64, 2427-2479.

Wang, H., Zhou, Y., Zhou, H., 2013. Credit default swap spreads and variance risk premia. Journal of Banking and Finance 37, 3733-3746.

Zhou, H., 2010. Variance risk premia, asset predictability puzzles, and macroeconomic uncertainty. Unpublished working paper. Federal Reserve Board, Washington, DC. 
Table 1

Volatility risk premia: descriptive statistics and betas, portfolios sorted by volatility risk premium betas, January 1996 to February 2011

The volatility risk premium $(V R P)$ for each portfolio is defined as the difference between the realized volatility and the model-free risk-neutral integrated return volatility over the corresponding month. The risk-neutral volatility is obtained by the set of prices of options on each underlying individual security with one month to maturity. The numbers reported are the annualized volatility risk premia for both the 20 portfolios and the Standard \& Poor's (S\&P) 100 Index. Portfolio 1 contains the securities with the lowest VRP betas, and Portfolio 20 has securities with the highest VRP betas. The portfolios are updated each month during the sample period. Both the volatility risk premium betas and the market betas are estimated with monthly observations. The $V R P$ betas are the ordinary least squares (OLS) regression coefficients of the monthly $V R P$ of each portfolio on the VRP of the S\&P 100 market index. The market return betas are the OLS regression coefficients of the monthly return of each portfolio on the market return index given by either the S\&P 100 Index or the overall US value-weighted market return of all Center for Research in Security Prices firms listed on the NYSE, Amex, or Nasdaq. The monthly data refer to the observation of each portfolio on the last day of each month. The betas are always estimated at the monthly frequency. The relative bid-ask spread is the average bid-ask spread for all traded options on the underlying stock that belong to a given portfolio calculated at the end of the last day of each month.

\begin{tabular}{|c|c|c|c|c|c|c|c|c|}
\hline $\begin{array}{c}V R P \text { beta- } \\
\text { sorted } \\
\text { portfolio }\end{array}$ & $\begin{array}{c}\text { Average } \\
V R P \\
\text { (monthly) } \\
\text { (1) }\end{array}$ & $\begin{array}{l}\text { Average } \\
\text { VRP } \\
\text { (daily) } \\
\text { (2) }\end{array}$ & $\begin{array}{c}\text { Standard } \\
\text { deviation } \\
\text { (monthly) } \\
\text { (3) }\end{array}$ & $\begin{array}{l}\text { Standard } \\
\text { deviation } \\
\text { (daily) } \\
\text { (4) }\end{array}$ & $\begin{array}{l}V R P \text { beta } \\
\text { (S\&P100 } \\
\text { market } \\
V R P) \\
(5)\end{array}$ & $\begin{array}{l}\text { Market } \\
\text { return beta } \\
\text { (overall US } \\
\text { market) } \\
(6)\end{array}$ & $\begin{array}{c}\text { Market } \\
\text { return beta } \\
\text { (S\&P } 100 \\
\text { market) } \\
(7)\end{array}$ & $\begin{array}{c}\text { Relative } \\
\text { bid-ask } \\
\text { spread } \\
\text { (8) }\end{array}$ \\
\hline P1B & 0.103 & 0.101 & 0.179 & 0.188 & -0.946 & 1.164 & 1.168 & 0.257 \\
\hline P2B & 0.040 & 0.043 & 0.092 & 0.096 & -0.229 & 1.042 & 1.050 & 0.256 \\
\hline P3B & 0.024 & 0.023 & 0.082 & 0.080 & 0.056 & 0.893 & 0.922 & 0.259 \\
\hline P4B & 0.018 & 0.014 & 0.072 & 0.067 & 0.223 & 1.017 & 1.008 & 0.265 \\
\hline P5B & 0.009 & 0.005 & 0.066 & 0.061 & 0.307 & 0.758 & 0.771 & 0.260 \\
\hline P6B & 0.001 & -0.002 & 0.062 & 0.060 & 0.368 & 0.890 & 0.897 & 0.270 \\
\hline P7B & -0.002 & -0.006 & 0.067 & 0.063 & 0.511 & 0.884 & 0.918 & 0.268 \\
\hline P8B & -0.004 & -0.010 & 0.067 & 0.063 & 0.558 & 0.964 & 0.987 & 0.261 \\
\hline P9B & -0.010 & -0.016 & 0.069 & 0.065 & 0.704 & 0.850 & 0.851 & 0.270 \\
\hline P10B & -0.010 & -0.017 & 0.077 & 0.073 & 0.819 & 0.931 & 0.977 & 0.273 \\
\hline P11B & -0.019 & -0.023 & 0.079 & 0.076 & 0.919 & 0.867 & 0.868 & 0.269 \\
\hline P12B & -0.021 & -0.027 & 0.086 & 0.083 & 1.011 & 0.949 & 0.958 & 0.281 \\
\hline P13B & -0.026 & -0.030 & 0.088 & 0.090 & 1.009 & 0.823 & 0.874 & 0.275 \\
\hline P14B & -0.022 & -0.032 & 0.099 & 0.099 & 1.219 & 0.972 & 1.013 & 0.279 \\
\hline P15B & -0.028 & -0.034 & 0.106 & 0.111 & 1.327 & 1.012 & 1.020 & 0.278 \\
\hline P16B & -0.031 & -0.037 & 0.119 & 0.125 & 1.444 & 0.873 & 0.935 & 0.277 \\
\hline P17B & -0.029 & -0.039 & 0.139 & 0.139 & 1.782 & 1.138 & 1.142 & 0.283 \\
\hline P18B & -0.029 & -0.043 & 0.165 & 0.162 & 2.068 & 1.163 & 1.164 & 0.281 \\
\hline P19B & -0.035 & -0.046 & 0.192 & 0.193 & 2.420 & 1.233 & 1.241 & 0.286 \\
\hline P20B & -0.034 & -0.045 & 0.312 & 0.318 & 3.891 & 1.463 & 1.521 & 0.296 \\
\hline Market $V R P$ & -0.014 & -0.014 & 0.069 & 0.069 & 1.000 & 0.929 & 1.000 & - \\
\hline
\end{tabular}


Table 2

Correlation coefficients between the volatility risk premia $(V R P)$ for representative VRP beta-sorted portfolios, January 1996 to February 2011

This table reports the correlation coefficients estimated for the overall sample period using monthly (daily) data for the volatility risk premia of the representative portfolios. The volatility risk premium for each portfolio is defined as the difference between the realized volatility and the model-free risk-neutral integrated return volatility over the corresponding month. The risk-neutral volatility is obtained by the set of prices of options on each underlying individual security with one month to maturity. Portfolio 1 contains the securities with the lowest VRP betas, and Portfolio 20 has securities with the highest VRP betas. The portfolios are updated each month during the sample period.

\begin{tabular}{|c|c|c|c|c|c|}
\hline Portfolio & P5B & P10B & P15B & P20B & $\begin{array}{c}\text { Market } \\
V R P\end{array}$ \\
\hline \multicolumn{6}{|c|}{$\begin{array}{l}\text { Panel A: Monthly } \\
\text { correlations }\end{array}$} \\
\hline $\mathrm{P} 1 \mathrm{~B}$ & 0.414 & -0.152 & -0.381 & -0.452 & -0.366 \\
\hline P5B & 1 & 0.607 & 0.314 & 0.194 & 0.323 \\
\hline P10B & & 1 & 0.834 & 0.726 & 0.736 \\
\hline P15B & & & 1 & 0.927 & 0.863 \\
\hline Р20B & & & & 1 & 0.863 \\
\hline \multicolumn{6}{|l|}{$\begin{array}{l}\text { Panel B: Daily } \\
\text { correlations }\end{array}$} \\
\hline P1B & 0.427 & -0.183 & -0.441 & -0.538 & -0.435 \\
\hline P5B & 1 & 0.589 & 0.333 & 0.155 & 0.231 \\
\hline P10B & & 1 & 0.865 & 0.685 & 0.733 \\
\hline P15B & & & 1 & 0.911 & 0.828 \\
\hline P20B & & & & 1 & 0.841 \\
\hline
\end{tabular}


Table 3

Ordinary least squares (OLS) estimators of volatility betas relative to different combinations of volatility, market return, interest rate, and consumption factors for five representative portfolios sorted by the volatility risk premium $(V R P)$ betas, January 1996 to February 2011

This table reports the OLS risk premium volatility betas. The volatility risk premium for each portfolio is defined as the difference between the realized volatility and the model-free risk-neutral integrated return volatility over the corresponding month. The risk-neutral volatility is obtained by the set of prices of options on each underlying individual security with one month to maturity. Portfolio 1 contains the securities with the lowest $V R P$ betas, and Portfolio 20 has securities with the highest $V R P$ betas. The portfolios are updated each month during the sample period. The $V R P$ beta is the OLS regression coefficient from linear regressions of the monthly $V R P$ of each portfolio on the VRP of the Standard \& Poor's (S\&P) 100 market index, consumption growth, stockholder consumption growth, the US stock market return, and the default premium (DEF). The monthly data refer to the observation of each portfolio on the last day of each month. The betas are always estimated at the monthly frequency.

\begin{tabular}{|c|c|c|c|c|c|c|c|}
\hline \multicolumn{8}{|c|}{ Panel A: Market volatility, market return, and consumption volatility betas } \\
\hline $\begin{array}{l}V R P \text { beta-sorted } \\
\text { portfolio }\end{array}$ & $\begin{array}{c}\text { Market } V R P \\
\text { (1) }\end{array}$ & $\begin{array}{c}\text { Market } \\
V R P \\
(2)\end{array}$ & $\begin{array}{c}\text { Excess } \\
\text { market return } \\
\text { (3) }\end{array}$ & $\begin{array}{l}\text { Consumption } \\
\text { growth } \\
\text { (4) }\end{array}$ & $\begin{array}{c}\text { Market } \\
V R P \\
(5)\end{array}$ & $\begin{array}{c}\text { Excess } \\
\text { market return } \\
\text { (6) }\end{array}$ & $\begin{array}{l}\text { Stockholder } \\
\text { consumption } \\
\text { growth } \\
\text { (7) }\end{array}$ \\
\hline $\begin{array}{l}\text { P1B beta } \\
\text { (t-statistic) } \\
\text { [Adjusted } \mathrm{R}^{2} \text { ] }\end{array}$ & $\begin{array}{l}-0.946 \\
(-5.28) \\
{[0.129]}\end{array}$ & $\begin{array}{c}-0.764 \\
(-4.18) \\
{[0.178]}\end{array}$ & $\begin{array}{l}0.257 \\
(3.43)\end{array}$ & $\begin{array}{l}0.440 \\
(0.31)\end{array}$ & $\begin{array}{l}-0.757 \\
(-4.14) \\
{[0.178]}\end{array}$ & $\begin{array}{l}0.307 \\
(2.65)\end{array}$ & $\begin{array}{l}-0.255 \\
(-0.51)\end{array}$ \\
\hline $\begin{array}{l}\text { P5B beta } \\
\text { (t-statistic) } \\
\text { [Adjusted } \mathrm{R}^{2} \text { ] }\end{array}$ & $\begin{array}{c}0.307 \\
(4.58) \\
{[0.100]}\end{array}$ & $\begin{array}{c}0.402 \\
(6.04) \\
{[0.193]}\end{array}$ & $\begin{array}{l}0.116 \\
(4.25)\end{array}$ & $\begin{array}{l}0.748 \\
(1.43)\end{array}$ & $\begin{array}{c}0.386 \\
(5.76) \\
{[0.184]}\end{array}$ & $\begin{array}{l}0.113 \\
(2.66)\end{array}$ & $\begin{array}{l}0.054 \\
(0.30)\end{array}$ \\
\hline $\begin{array}{l}\text { P10B beta } \\
\text { (t-statistic) } \\
\text { [Adjusted } \mathrm{R}^{2} \text { ] }\end{array}$ & $\begin{array}{c}0.819 \\
(14.61) \\
{[0.540]}\end{array}$ & $\begin{array}{c}0.873 \\
(15.37) \\
{[0.571]}\end{array}$ & $\begin{array}{l}0.026 \\
(1.11)\end{array}$ & $\begin{array}{l}1.561 \\
(3.49)\end{array}$ & $\begin{array}{c}0.844 \\
(14.35) \\
{[0.542]}\end{array}$ & $\begin{array}{l}0.033 \\
(0.89)\end{array}$ & $\begin{array}{l}0.037 \\
(0.23)\end{array}$ \\
\hline $\begin{array}{l}\text { P15B beta } \\
\text { (t-statistic) } \\
\text { [Adjusted } \mathrm{R}^{2} \text { ] }\end{array}$ & $\begin{array}{c}1.327 \\
(22.94) \\
{[0.744]}\end{array}$ & $\begin{array}{c}1.327 \\
(22.45) \\
{[0.757]}\end{array}$ & $\begin{array}{l}-0.050 \\
(-2.08)\end{array}$ & $\begin{array}{l}1.429 \\
(3.07)\end{array}$ & $\begin{array}{c}1.294 \\
(21.35) \\
{[0.745]}\end{array}$ & $\begin{array}{l}-0.063 \\
(-1.63)\end{array}$ & $\begin{array}{l}0.138 \\
(0.84)\end{array}$ \\
\hline $\begin{array}{l}\text { P20B beta } \\
\text { (t-statistic) } \\
\text { [Adjusted } \mathrm{R}^{2} \text { ] }\end{array}$ & $\begin{array}{c}3.891 \\
(22.87) \\
{[0.743]}\end{array}$ & $\begin{array}{c}3.769 \\
(21.58) \\
{[0.754]}\end{array}$ & $\begin{array}{l}-0.227 \\
(-3.17)\end{array}$ & $\begin{array}{l}1.292 \\
(0.94)\end{array}$ & $\begin{array}{c}3.706 \\
(21.28) \\
{[0.756]}\end{array}$ & $\begin{array}{l}-0.347 \\
(-3.15)\end{array}$ & $\begin{array}{l}0.732 \\
(1.55)\end{array}$ \\
\hline
\end{tabular}

\begin{tabular}{|c|c|c|c|c|c|c|c|}
\hline $\begin{array}{l}V R P \text { beta-sorted } \\
\text { portfolio }\end{array}$ & $\begin{array}{c}\text { Market } V R P \\
\text { (1) }\end{array}$ & $\begin{array}{c}\text { Market } \\
V R P \\
(2)\end{array}$ & $\begin{array}{c}\text { Excess } \\
\text { market return } \\
\text { (3) }\end{array}$ & $\begin{array}{c}\text { DEF } \\
(4)\end{array}$ & $\begin{array}{c}\text { Market } \\
V R P \\
(5)\end{array}$ & $\begin{array}{l}\text { Consumption } \\
\text { growth } \\
\text { (6) }\end{array}$ & $\begin{array}{l}\mathrm{DEF} \\
(7)\end{array}$ \\
\hline $\begin{array}{l}\text { P1B beta } \\
\text { (t-statistic) } \\
\text { [Adjusted } \mathrm{R}^{2} \text { ] }\end{array}$ & $\begin{array}{l}-0.946 \\
(-5.28) \\
{[0.129]}\end{array}$ & $\begin{array}{l}-0.777 \\
(-4.30) \\
{[0.180]}\end{array}$ & $\begin{array}{l}0.267 \\
(3.60)\end{array}$ & $\begin{array}{l}0.296 \\
(0.75)\end{array}$ & $\begin{array}{l}-0.917 \\
(-5.02) \\
{[0.126]}\end{array}$ & $\begin{array}{l}1.648 \\
(1.06)\end{array}$ & $\begin{array}{l}0.290 \\
(0.67)\end{array}$ \\
\hline $\begin{array}{l}\text { P5B beta } \\
\text { (t-statistic) } \\
\text { [Adjusted } \mathrm{R}^{2} \text { ] }\end{array}$ & $\begin{array}{c}0.307 \\
(4.58) \\
{[0.100]}\end{array}$ & $\begin{array}{c}0.393 \\
(5.98) \\
{[0.196]}\end{array}$ & $\begin{array}{l}0.117 \\
(4.34)\end{array}$ & $\begin{array}{l}-0.242 \\
(-1.69)\end{array}$ & $\begin{array}{c}0.334 \\
(4.97) \\
{[0.122]}\end{array}$ & $\begin{array}{l}0.834 \\
(1.45)\end{array}$ & $\begin{array}{l}-0.234 \\
(-1.47)\end{array}$ \\
\hline $\begin{array}{l}\text { P10B beta } \\
\text { (t-statistic) } \\
\text { [Adjusted } \mathrm{R}^{2} \text { ] }\end{array}$ & $\begin{array}{c}0.819 \\
(14.61) \\
{[0.540]}\end{array}$ & $\begin{array}{c}0.856 \\
(15.48) \\
{[0.587]}\end{array}$ & $\begin{array}{l}0.028 \\
(1.25)\end{array}$ & $\begin{array}{l}-0.531 \\
(-4.40)\end{array}$ & $\begin{array}{c}0.860 \\
(16.06) \\
{[0.596]}\end{array}$ & $\begin{array}{l}1.088 \\
(2.38)\end{array}$ & $\begin{array}{l}-0.443 \\
(-3.50)\end{array}$ \\
\hline $\begin{array}{l}\text { P15B beta } \\
\text { (t-statistic) } \\
\text { [Adjusted } \mathrm{R}^{2} \text { ] }\end{array}$ & $\begin{array}{c}1.327 \\
(22.94) \\
{[0.744]}\end{array}$ & $\begin{array}{c}1.309 \\
(22.37) \\
{[0.758]}\end{array}$ & $\begin{array}{l}-0.046 \\
(-1.94)\end{array}$ & $\begin{array}{l}-0.402 \\
(-3.15)\end{array}$ & $\begin{array}{c}1.358 \\
(23.69) \\
{[0.757]}\end{array}$ & $\begin{array}{l}0.903 \\
(1.85)\end{array}$ & $\begin{array}{l}-0.286 \\
(-2.11)\end{array}$ \\
\hline $\begin{array}{l}\text { P20B beta } \\
\text { (t-statistic) } \\
\text { [Adjusted } \mathrm{R}^{2} \text { ] }\end{array}$ & $\begin{array}{c}3.891 \\
(22.87) \\
{[0.743]}\end{array}$ & $\begin{array}{c}3.747 \\
(21.60) \\
{[0.753]}\end{array}$ & $\begin{array}{l}-0.217 \\
(-3.04)\end{array}$ & $\begin{array}{l}-0.053 \\
(-0.14)\end{array}$ & $\begin{array}{c}3.903 \\
(22.42) \\
{[0.740]}\end{array}$ & $\begin{array}{l}0.739 \\
(0.50)\end{array}$ & $\begin{array}{l}0.152 \\
(0.37)\end{array}$ \\
\hline
\end{tabular}




\section{Table 4}

Two-pass cross-sectional Fama and MacBeth estimation for alternative volatility risk premium models, using portfolios sorted by the volatility risk premium betas, January 1996 to February 2011

We report the parameter estimated from the two-pass cross-sectional regression with rolling betas for alternative asset pricing models. NDC and SHC denote nondurable consumption and stockholder consumption, respectively. MAE is the mean pricing errors associated with the 20 portfolios ranked by their volatility risk premium betas. The $R^{2}$ value is the sample cross-sectional $R^{2}$ as calculated by (Kan, Robotti, and Shanken, 2013). The numbers in parentheses are the $p$-values of traditional Fama and MacBeth standard errors of the alternative parameter estimates and the numbers in brackets are $p$-values associated with the Kan, Robotti, and Shanken standard errors adjusted by errors-in-the variables and potential misspecification of the models. Below the crosssectional $R^{2}$ values, we report the $p$-value for the test of $H_{0}: R^{2}=0$ and in brackets we display the standard error of $R^{2}$ under the assumption that $0<R^{2}<1$. SDF refers to stochastic discount factor.

\begin{tabular}{|c|c|c|c|c|c|c|c|c|c|c|}
\hline & $\lambda_{0}$ & $\lambda_{n d c}$ & $\lambda_{s h c}$ & $\lambda_{m}$ & $\lambda_{m}^{2}$ & $\lambda_{v r p}^{m}$ & $\lambda_{d e f}$ & $\lambda_{h m l}$ & $M A E$ & $R^{2}$ \\
\hline $\begin{array}{l}\text { Panel A: } \\
\text { Consumption- } \\
\text { based SDF }\end{array}$ & & & & & & & & & & \\
\hline $\begin{array}{l}\text { Recursive } R_{m} \\
\text { NDC }\end{array}$ & $\begin{array}{l}-0.003 \\
(0.015) \\
{[0.356]}\end{array}$ & $\begin{array}{c}0.003 \\
(0.000) \\
{[0.510]}\end{array}$ & - & $\begin{array}{c}0.064 \\
(0.000) \\
{[0.054]}\end{array}$ & - & - & - & - & 0.0029 & $\begin{array}{l}0.0635 \\
(0.803) \\
{[0.369]}\end{array}$ \\
\hline $\begin{array}{l}\text { Recursive } R_{m} \\
\text { SHC }\end{array}$ & $\begin{array}{l}-0.000 \\
(0.764) \\
{[0.763]}\end{array}$ & - & $\begin{array}{c}0.004 \\
(0.039) \\
{[0.507]}\end{array}$ & $\begin{array}{c}0.031 \\
(0.000) \\
{[0.161]}\end{array}$ & - & - & - & - & 0.0033 & $\begin{array}{l}0.0541 \\
(0.627) \\
{[0.163]}\end{array}$ \\
\hline $\begin{array}{l}\text { Recursive } V R P^{m} \\
\text { NDC }\end{array}$ & $\begin{array}{c}0.002 \\
(0.075) \\
{[0.509]}\end{array}$ & $\begin{array}{c}0.002 \\
(0.003) \\
{[0.608]}\end{array}$ & - & - & - & $\begin{array}{l}-0.007 \\
(0.000) \\
{[0.027]}\end{array}$ & - & - & 0.0028 & $\begin{array}{l}0.1290 \\
(0.417) \\
{[0.284]}\end{array}$ \\
\hline $\begin{array}{l}\text { Recursive } V R P^{m} \\
\text { SHC }\end{array}$ & $\begin{array}{c}0.002 \\
(0.103) \\
{[0.213]}\end{array}$ & - & $\begin{array}{c}0.001 \\
(0.749) \\
{[0.931]}\end{array}$ & - & - & $\begin{array}{l}-0.007 \\
(0.000) \\
{[0.153]}\end{array}$ & - & - & 0.0031 & $\begin{array}{l}0.0873 \\
(0.462) \\
{[0.170]}\end{array}$ \\
\hline \multicolumn{11}{|l|}{$\begin{array}{l}\text { Panel B: } \\
\text { Factor-based SDF }\end{array}$} \\
\hline$R_{m}+R_{m}^{2}$ & $\begin{array}{c}0.001 \\
(0.550) \\
{[0.648]}\end{array}$ & - & - & $\begin{array}{c}0.036 \\
(0.000) \\
{[0.014]}\end{array}$ & $\begin{array}{c}0.001 \\
(0.041) \\
{[0.295]}\end{array}$ & - & - & - & 0.0022 & $\begin{array}{l}0.1031 \\
(0.193) \\
{[0.148]}\end{array}$ \\
\hline$V R P^{m}$ & $\begin{array}{c}0.005 \\
(0.000) \\
{[0.001]}\end{array}$ & - & - & - & - & $\begin{array}{l}-0.006 \\
(0.000) \\
{[0.109]}\end{array}$ & - & - & 0.0035 & $\begin{array}{l}0.0879 \\
(0.148) \\
{[0.173]}\end{array}$ \\
\hline $\begin{array}{l}V R P^{m}+D E F \\
+H M L+R_{m}\end{array}$ & $\begin{array}{c}0.009 \\
(0.000) \\
{[0.002]}\end{array}$ & - & - & $\begin{array}{l}-0.010 \\
(0.154) \\
{[0.658]}\end{array}$ & - & $\begin{array}{l}-0.007 \\
(0.000) \\
{[0.049]}\end{array}$ & $\begin{array}{c}0.014 \\
(0.000) \\
{[0.000]}\end{array}$ & $\begin{array}{c}0.019 \\
(0.006) \\
{[0.335]}\end{array}$ & 0.0016 & $\begin{array}{l}0.5341 \\
(0.017) \\
{[0.219]}\end{array}$ \\
\hline$V R P^{m}+D E F$ & $\begin{array}{c}0.007 \\
(0.000) \\
{[0.006]}\end{array}$ & - & - & - & - & $\begin{array}{l}-0.006 \\
(0.000) \\
{[0.049]}\end{array}$ & $\begin{array}{c}0.012 \\
(0.000) \\
{[0.000]}\end{array}$ & - & 0.0019 & $\begin{array}{l}0.5139 \\
(0.001) \\
{[0.211]}\end{array}$ \\
\hline
\end{tabular}




\section{Table 5}

Model comparison using the two-pass cross-sectional Fama and Macbeth estimation for portfolios sorted by the volatility risk premium betas: tests of the equality of the cross-sectional $R^{2}$ values

This table shows the results of pairwise tests of equality of the ordinary least squares two-pass cross-sectional $R^{2}$ values for alternative asset pricing models. NDC and SHC denote nondurable consumption and stockholder consumption, respectively. We report the difference between the sample cross-sectional $R^{2}$ values of the models in row $i$ and column $j, \hat{R}_{i}^{2}-\hat{R}_{j}^{2}$, and the associated $p$-values in parentheses for the test of $H_{0}: \hat{R}_{i}^{2}=\hat{R}_{j}^{2}$. The $p$-values are computed under the assumption that the models are potentially misspecified.

\begin{tabular}{|c|c|c|c|c|c|c|c|}
\hline Model & $\begin{array}{c}\text { Recursive } \\
\text { SHC } \\
R_{m} \\
\end{array}$ & $\begin{array}{c}\text { Recursive } \\
\text { NDC } \\
V R P^{m} \\
\end{array}$ & $\begin{array}{c}\text { Recursive } \\
\text { SHC } \\
V R P^{m} \\
\end{array}$ & $R_{m}+R_{m}^{2}$ & $V R P^{m}$ & $\begin{array}{c}V R P^{m} \\
+D E F \\
+H M L \\
+R_{m} \\
\end{array}$ & $\begin{array}{l}V R P^{m} \\
+D E F \\
\end{array}$ \\
\hline $\begin{array}{l}\text { Recursive } \\
\text { NDC } \\
R_{m}\end{array}$ & $\begin{array}{l}0.0094 \\
(0.974)\end{array}$ & $\begin{array}{c}-0.0655 \\
(0.810)\end{array}$ & $\begin{array}{c}-0.0237 \\
(0.945)\end{array}$ & $\begin{array}{c}-0.0396 \\
(0.903)\end{array}$ & $\begin{array}{c}-0.0243 \\
(0.945)\end{array}$ & $\begin{array}{c}-0.4705 \\
(0.278)\end{array}$ & $\begin{array}{l}-0.4504 \\
(0.286)\end{array}$ \\
\hline $\begin{array}{l}\text { Recursive } \\
\text { SHC } \\
R_{m}\end{array}$ & & $\begin{array}{r}-0.0749 \\
(0.788)\end{array}$ & $\begin{array}{c}-0.0332 \\
(0.841)\end{array}$ & $\begin{array}{c}-0.0490 \\
(0.704)\end{array}$ & $\begin{array}{c}-0.0388 \\
(0.840)\end{array}$ & $\begin{array}{c}-0.4800 \\
(0.089)\end{array}$ & $\begin{array}{l}-0.4598 \\
(0.082)\end{array}$ \\
\hline $\begin{array}{l}\text { Recursive } \\
\text { NDC } \\
V R P^{m}\end{array}$ & & & $\begin{array}{l}0.0418 \\
(0.863)\end{array}$ & $\begin{array}{l}0.0259 \\
(0.923)\end{array}$ & $\begin{array}{l}0.0412 \\
(0.865)\end{array}$ & $\begin{array}{c}-0.4050 \\
(0.200)\end{array}$ & $\begin{array}{l}-0.3849 \\
(0.212)\end{array}$ \\
\hline $\begin{array}{l}\text { Recursive } \\
\text { SHC } \\
V R P^{m}\end{array}$ & & & & $\begin{array}{c}-0.0158 \\
(0.923)\end{array}$ & $\begin{array}{c}-0.0006 \\
(0.995)\end{array}$ & $\begin{array}{c}-0.4468 \\
(0.036)\end{array}$ & $\begin{array}{l}-0.4266 \\
(0.039)\end{array}$ \\
\hline$R_{m}+R_{m}^{2}$ & & & & & $\begin{array}{l}0.0152 \\
(0.926)\end{array}$ & $\begin{array}{c}-0.4310 \\
(0.076)\end{array}$ & $\begin{array}{l}-0.4108 \\
(0.070)\end{array}$ \\
\hline$V R P^{m}$ & & & & & & $\begin{array}{c}-0.4462 \\
(0.043)\end{array}$ & $\begin{array}{l}-0.4108 \\
(0.044)\end{array}$ \\
\hline $\begin{array}{l}V R P^{m} \\
+D E F \\
+H M L+R_{m}\end{array}$ & & & & & & & $\begin{array}{l}0.0202 \\
(0.860)\end{array}$ \\
\hline
\end{tabular}


Table 6

Portfolio return and volatility risk premium (VRP) sensitivities to the default premium and financial stress, January 1996 to February 2011

This table employs the returns of the underlying components of representative $V R P$ beta-sorted portfolios to estimate the default and financial stress betas controlling for market returns. The first column reports the return betas with respect to the default premium, and the second column reports the betas with respect to the St. Louis Fed Financial Stress Index (STLFSI). The STLFSI measures the degree of financial stress in the markets, where increasing values of the index represents higher financial stress risk. The last column displays the $V R P$ betas of the $20 \mathrm{VRP}$ beta-sorted portfolios with respect to STLFSI. NBER refers to the National Bureau of Economic Research, and USSLIND is the Leading Index for the US economy. $t$-statistics are reported in parentheses.

\begin{tabular}{|c|c|c|c|c|c|c|c|}
\hline $\begin{array}{c}V R P \text { beta- } \\
\text { sorted } \\
\text { portfolio }\end{array}$ & $\begin{array}{l}\text { Default } \\
\text { return } \\
\text { betas } \\
(1)\end{array}$ & $\begin{array}{c}\text { Financial } \\
\text { stress } \\
\text { return betas } \\
(2)\end{array}$ & $\begin{array}{c}\text { Default } \\
\text { betas } \\
\times \\
\text { NBER } \\
(3)\end{array}$ & $\begin{array}{c}\text { Default } \\
\text { betas } \\
\times \\
\text { USSLIND } \\
(4) \\
\end{array}$ & $\begin{array}{c}\text { Stress betas } \\
\times \\
\text { NBER } \\
(5) \\
\end{array}$ & $\begin{array}{c}\text { Stress betas } \\
\times \\
\text { USSLIND } \\
(6) \\
\end{array}$ & $\begin{array}{c}\text { Financial } \\
\text { stress } \\
\text { volatility } \\
\text { betas } \\
(7) \\
\end{array}$ \\
\hline P1B & $\begin{array}{c}1.571 \\
(2.00)\end{array}$ & $\begin{array}{l}0.011 \\
(1.61)\end{array}$ & $\begin{array}{l}0.534 \\
(1.08)\end{array}$ & $\begin{array}{c}0.964 \\
(1.97)\end{array}$ & $\begin{array}{l}0.394 \\
(2.68)\end{array}$ & $\begin{array}{l}0.022 \\
(2.76)\end{array}$ & $\begin{array}{c}-0.0018 \\
(-0.49)\end{array}$ \\
\hline P2B & $\begin{array}{l}1.208 \\
(2.82)\end{array}$ & $\begin{array}{l}0.012 \\
(3.25)\end{array}$ & $\begin{array}{l}0.688 \\
(2.55)\end{array}$ & $\begin{array}{l}0.912 \\
(3.45)\end{array}$ & $\begin{array}{c}0.261 \\
(3.25)\end{array}$ & $\begin{array}{l}0.016 \\
(3.68)\end{array}$ & $\begin{array}{c}-0.0021 \\
(-1.17)\end{array}$ \\
\hline P3B & $\begin{array}{l}0.973 \\
(2.15)\end{array}$ & $\begin{array}{l}0.011 \\
(2.92)\end{array}$ & $\begin{array}{l}0.350 \\
(1.22)\end{array}$ & $\begin{array}{l}0.643 \\
(2.28)\end{array}$ & $\begin{array}{l}0.173 \\
(2.01)\end{array}$ & $\begin{array}{l}0.011 \\
(2.43)\end{array}$ & $\begin{array}{c}-0.0024 \\
(-1.50)\end{array}$ \\
\hline P4B & $\begin{array}{l}0.521 \\
(1.43)\end{array}$ & $\begin{array}{l}0.006 \\
(1.93)\end{array}$ & $\begin{array}{l}0.265 \\
(1.16)\end{array}$ & $\begin{array}{l}0.421 \\
(1.86)\end{array}$ & $\begin{array}{l}0.080 \\
(1.16)\end{array}$ & $\begin{array}{l}0.005 \\
(1.45)\end{array}$ & $\begin{array}{c}-0.0012 \\
(-0.85)\end{array}$ \\
\hline P5B & $\begin{array}{c}1.144 \\
(3.34)\end{array}$ & $\begin{array}{l}0.008 \\
(2.66)\end{array}$ & $\begin{array}{l}0.278 \\
(1.26)\end{array}$ & $\begin{array}{c}0.574 \\
(2.66)\end{array}$ & $\begin{array}{l}0.128 \\
(1.94)\end{array}$ & $\begin{array}{l}0.008 \\
(2.37)\end{array}$ & $\begin{array}{c}-0.0002 \\
(-0.15)\end{array}$ \\
\hline P10B & $\begin{array}{l}0.077 \\
(0.26)\end{array}$ & $\begin{array}{l}0.004 \\
(1.45)\end{array}$ & $\begin{array}{l}0.051 \\
(0.27)\end{array}$ & $\begin{array}{l}0.086 \\
(0.47)\end{array}$ & $\begin{array}{l}0.039 \\
(0.70)\end{array}$ & $\begin{array}{l}0.002 \\
(0.66)\end{array}$ & $\begin{array}{c}0.0008 \\
(0.50)\end{array}$ \\
\hline P16B & $\begin{array}{l}-0.192 \\
(-0.57)\end{array}$ & $\begin{array}{l}-0.001 \\
(-0.30)\end{array}$ & $\begin{array}{l}-0.036 \\
(-0.17)\end{array}$ & $\begin{array}{l}-0.096 \\
(-0.46)\end{array}$ & $\begin{array}{l}0.059 \\
(0.94)\end{array}$ & $\begin{array}{l}0.003 \\
(1.01)\end{array}$ & $\begin{array}{c}0.0046 \\
(1.96)\end{array}$ \\
\hline P17B & $\begin{array}{l}-0.536 \\
(-1.60)\end{array}$ & $\begin{array}{l}-0.004 \\
(-1.31)\end{array}$ & $\begin{array}{l}-0.370 \\
(-1.76)\end{array}$ & $\begin{array}{l}-0.285 \\
(-1.36)\end{array}$ & $\begin{array}{l}-0.037 \\
(-0.59)\end{array}$ & $\begin{array}{l}-0.003 \\
(-0.82)\end{array}$ & $\begin{array}{c}0.0060 \\
(2.20)\end{array}$ \\
\hline P18B & $\begin{array}{l}-0.160 \\
(-0.45)\end{array}$ & $\begin{array}{l}-0.001 \\
(-0.16)\end{array}$ & $\begin{array}{l}-0.190 \\
(-0.85)\end{array}$ & $\begin{array}{l}-0.220 \\
(-0.99)\end{array}$ & $\begin{array}{l}-0.022 \\
(-0.33)\end{array}$ & $\begin{array}{l}-0.002 \\
(-0.58)\end{array}$ & $\begin{array}{c}0.0056 \\
(1.73)\end{array}$ \\
\hline P19B & $\begin{array}{l}-0.720 \\
(-2.06)\end{array}$ & $\begin{array}{l}-0.006 \\
(-2.12)\end{array}$ & $\begin{array}{l}-0.320 \\
(-1.95)\end{array}$ & $\begin{array}{l}-0.514 \\
(-2.37)\end{array}$ & $\begin{array}{l}-0.157 \\
(-2.39)\end{array}$ & $\begin{array}{l}-0.010 \\
(-2.78)\end{array}$ & $\begin{array}{c}0.0098 \\
(2.61)\end{array}$ \\
\hline P20B & $\begin{array}{l}-0.999 \\
(-2.02)\end{array}$ & $\begin{array}{l}-0.007 \\
(-1.97)\end{array}$ & $\begin{array}{l}-0.430 \\
(-1.87)\end{array}$ & $\begin{array}{l}-0.706 \\
(-2.29)\end{array}$ & $\begin{array}{l}-0.150 \\
(-1.70)\end{array}$ & $\begin{array}{l}-0.010 \\
(-1.96)\end{array}$ & $\begin{array}{c}0.0172 \\
(2.91)\end{array}$ \\
\hline
\end{tabular}


Table A1

Volatility risk premia $(V R P)$ : descriptive statistics and betas, portfolios sorted by volatility risk premium betas when the volatility risk premium estimates are adjusted by the mean, January 1996 to February 2011

The volatility risk premium for each portfolio is defined as the difference between the realized volatility and the model-free riskneutral integrated return volatility over the corresponding month. The risk-neutral volatility is obtained by the set of prices of options on each underlying individual security with one month to maturity. The numbers reported are the annualized volatility risk premia for both the 20 portfolios and the Standard \& Poor's (S\&P) 100 Index. Portfolio 1 contains the securities with the lowest VRP betas, and Portfolio 20 has securities with the highest VRP betas. The portfolios are updated each month during the sample period. The VRP beta is the ordinary least squares (OLS) regression coefficient from linear regressions of the monthly VRP of each portfolio on the VRP of the S\&P 100 market index. The market return betas are the OLS regression coefficients from linear regressions of the monthly return of each portfolio on the market return index given by either the S\&P 100 Index or the overall US value-weight market return of all Center for Research in Security Prices firms listed on the NYSE, Amex, or Nasdaq. The monthly data refer to the observation of each portfolio on the last day of each month. The betas are always estimated at the monthly frequency. The relative bid-ask spread is the average bid-ask spread for all traded options on the underlying stock that belong to a given portfolio calculated at the end of the last day of each month.

\begin{tabular}{|c|c|c|c|c|c|c|c|c|}
\hline $\begin{array}{c}V R P \text { beta- } \\
\text { sorted } \\
\text { portfolio }\end{array}$ & $\begin{array}{c}\text { Averag } \\
\text { e } V R P \\
\text { (monthl } \\
\text { y) }\end{array}$ & $\begin{array}{c}\text { Average } \\
V R P \\
\text { (daily) }\end{array}$ & $\begin{array}{l}\text { Standard } \\
\text { deviation } \\
\text { (monthly) }\end{array}$ & $\begin{array}{c}\text { Standard } \\
\text { deviation } \\
\text { (daily) }\end{array}$ & $\begin{array}{c}V R P \text { beta } \\
(\mathrm{S} \& \mathrm{P} 100 \\
\text { market } \\
V R P)\end{array}$ & $\begin{array}{l}\text { Market } \\
\text { return } \\
\text { beta } \\
\text { (overall } \\
\text { US } \\
\text { market) }\end{array}$ & $\begin{array}{c}\text { Market } \\
\text { return beta } \\
\text { (S\&P } 100 \\
\text { market) }\end{array}$ & $\begin{array}{c}\text { Relative } \\
\text { bid-ask } \\
\text { spread }\end{array}$ \\
\hline P1B & 0.100 & 0.100 & 0.176 & 0.185 & -0.880 & 1.122 & 1.127 & 0.256 \\
\hline $\mathrm{P} 2 \mathrm{~B}$ & 0.036 & 0.037 & 0.092 & 0.094 & -0.225 & 1.140 & 1.138 & 0.259 \\
\hline P3B & 0.020 & 0.020 & 0.077 & 0.075 & 0.068 & 0.830 & 0.869 & 0.260 \\
\hline P4B & 0.014 & 0.010 & 0.068 & 0.066 & 0.227 & 0.941 & 0.941 & 0.262 \\
\hline P5B & 0.004 & 0.002 & 0.066 & 0.062 & 0.328 & 0.800 & 0.813 & 0.263 \\
\hline P6B & 0.000 & -0.005 & 0.065 & 0.058 & 0.382 & 0.863 & 0.877 & 0.269 \\
\hline P7B & -0.006 & -0.009 & 0.069 & 0.063 & 0.506 & 0.892 & 0.919 & 0.269 \\
\hline P8B & -0.008 & -0.014 & 0.066 & 0.063 & 0.584 & 0.976 & 0.979 & 0.265 \\
\hline P9B & -0.014 & -0.020 & 0.068 & 0.067 & 0.665 & 0.799 & 0.825 & 0.265 \\
\hline P10B & -0.017 & -0.024 & 0.072 & 0.070 & 0.788 & 0.948 & 0.975 & 0.271 \\
\hline P11B & -0.021 & -0.026 & 0.079 & 0.076 & 0.949 & 0.973 & 0.989 & 0.272 \\
\hline P12B & -0.023 & -0.030 & 0.084 & 0.083 & 0.956 & 0.902 & 0.923 & 0.268 \\
\hline P13B & -0.031 & -0.037 & 0.088 & 0.090 & 1.026 & 0.823 & 0.850 & 0.280 \\
\hline P14B & -0.031 & -0.038 & 0.099 & 0.098 & 1.219 & 1.004 & 1.070 & 0.280 \\
\hline P15B & -0.033 & -0.040 & 0.104 & 0.110 & 1.250 & 1.027 & 1.019 & 0.282 \\
\hline P16B & -0.036 & -0.044 & 0.117 & 0.122 & 1.457 & 0.893 & 0.953 & 0.276 \\
\hline P17B & -0.036 & -0.045 & 0.134 & 0.137 & 1.723 & 1.074 & 1.088 & 0.278 \\
\hline P18B & -0.035 & -0.050 & 0.164 & 0.160 & 2.044 & 1.218 & 1.201 & 0.284 \\
\hline P19B & -0.043 & -0.055 & 0.188 & 0.189 & 2.385 & 1.206 & 1.219 & 0.286 \\
\hline P20B & -0.047 & -0.057 & 0.307 & 0.313 & 3.813 & 1.467 & 1.524 & 0.298 \\
\hline Market $V R P$ & -0.017 & -0.017 & 0.069 & 0.069 & 1.000 & 0.929 & 1.000 & - \\
\hline
\end{tabular}




\section{Table A2}

Correlation coefficients between state variables, January 1996 to February 2011

This table reports the correlation coefficients estimated for the overall sample period using monthly data. The market volatility risk premium is defined as the difference between the realized volatility and the model-free risk-neutral integrated return volatility over the corresponding month. The risk-neutral volatility is obtained by the set of prices of options on the Standard \& Poor's (S\&P) 100 Index with one month to maturity.

Consumption growth is the monthly growth rate of seasonally adjusted real per capita consumption expenditures on nondurables goods and services; stockholder consumption growth is the Malloy, Moskowitz, and Vissing-Jorgensen (2011) measure of consumption growth from stockholders; DEF is the default premium calculated as the difference between Moody's yield on Baa corporate bonds and the ten-year government bond yield; excess market return, SMB (small minus big), and HML (high minus low) are the Fama andFrench factors. Together with the momentum factor (MOM), they are obtained from the Kenneth French's website (http://mba.tuck.dartmouth.edu/pages/faculty/ken.french/).

\begin{tabular}{|c|c|c|c|c|c|c|c|}
\hline $\begin{array}{c}\text { Monthly } \\
\text { correlation }\end{array}$ & $\begin{array}{l}\text { Excess } \\
\text { market } \\
\text { return } \\
\end{array}$ & $\begin{array}{c}\text { Consumption } \\
\text { growth }\end{array}$ & $\begin{array}{c}\text { Stockholder } \\
\text { consumption } \\
\text { growth }\end{array}$ & DEF & SMB & HML & MOM \\
\hline Market $V R P$ & -0.273 & -0.189 & -0.118 & 0.075 & 0.019 & 0.130 & 0.185 \\
\hline $\begin{array}{l}\text { Excess } \\
\text { market } \\
\text { return }\end{array}$ & 1 & 0.213 & 0.769 & -0.132 & 0.242 & -0.247 & -0.296 \\
\hline $\begin{array}{l}\text { Consumption } \\
\text { growth }\end{array}$ & & 1 & 0.131 & -0.356 & 0.043 & -0.125 & -0.356 \\
\hline $\begin{array}{l}\text { Stockholder } \\
\text { consumption } \\
\text { growth }\end{array}$ & & & 1 & -0.149 & 0.449 & 0.237 & -0.301 \\
\hline $\mathrm{DEF}$ & & & & 1 & 0.058 & -0.087 & -0.198 \\
\hline SMB & & & & & 1 & -0.372 & 0.091 \\
\hline HML & & & & & & 1 & -0.156 \\
\hline
\end{tabular}




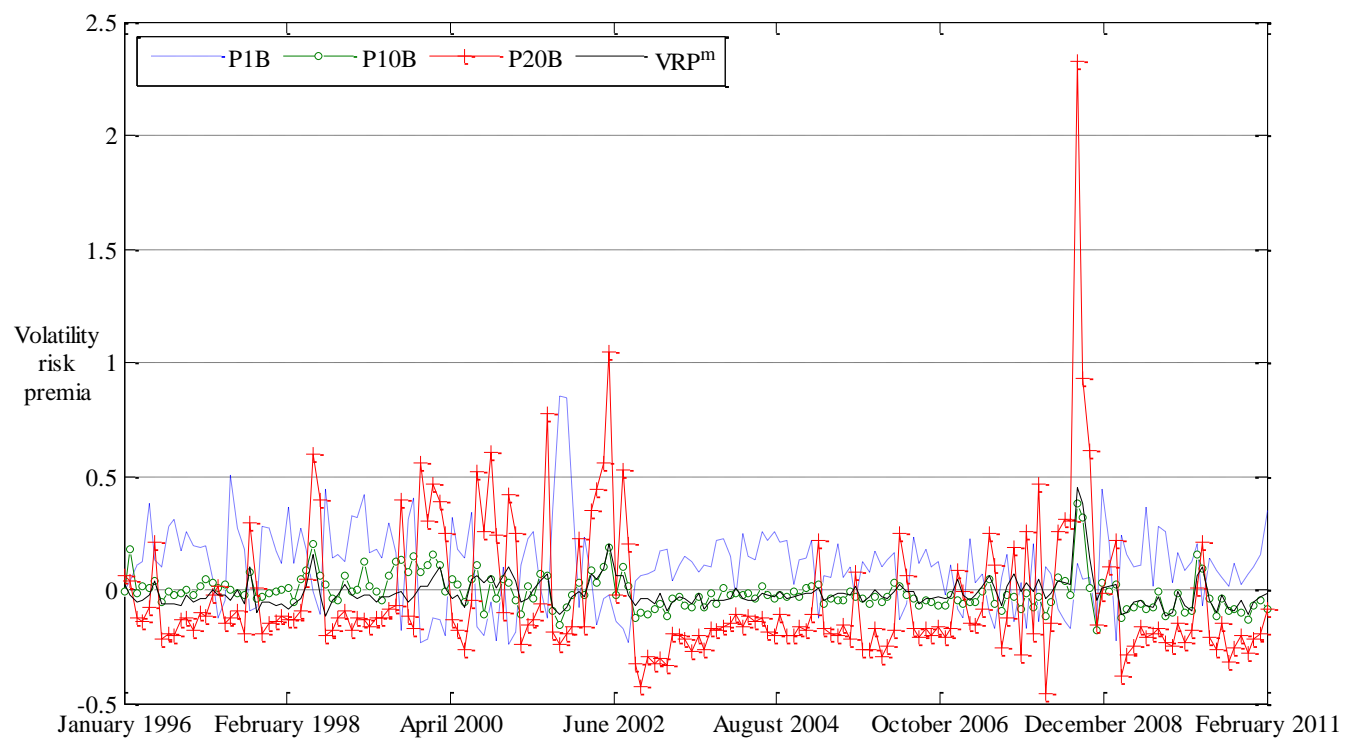

Fig. 1. Volatility risk premia for extreme and intermediate volatility risk premium (VRP) beta-sorted portfolios and the market: January 1996-February 2011. This figure displays the temporal behavior of representative volatility risk premium beta-sorted portfolios and the market volatility risk premium. 
Panel A:

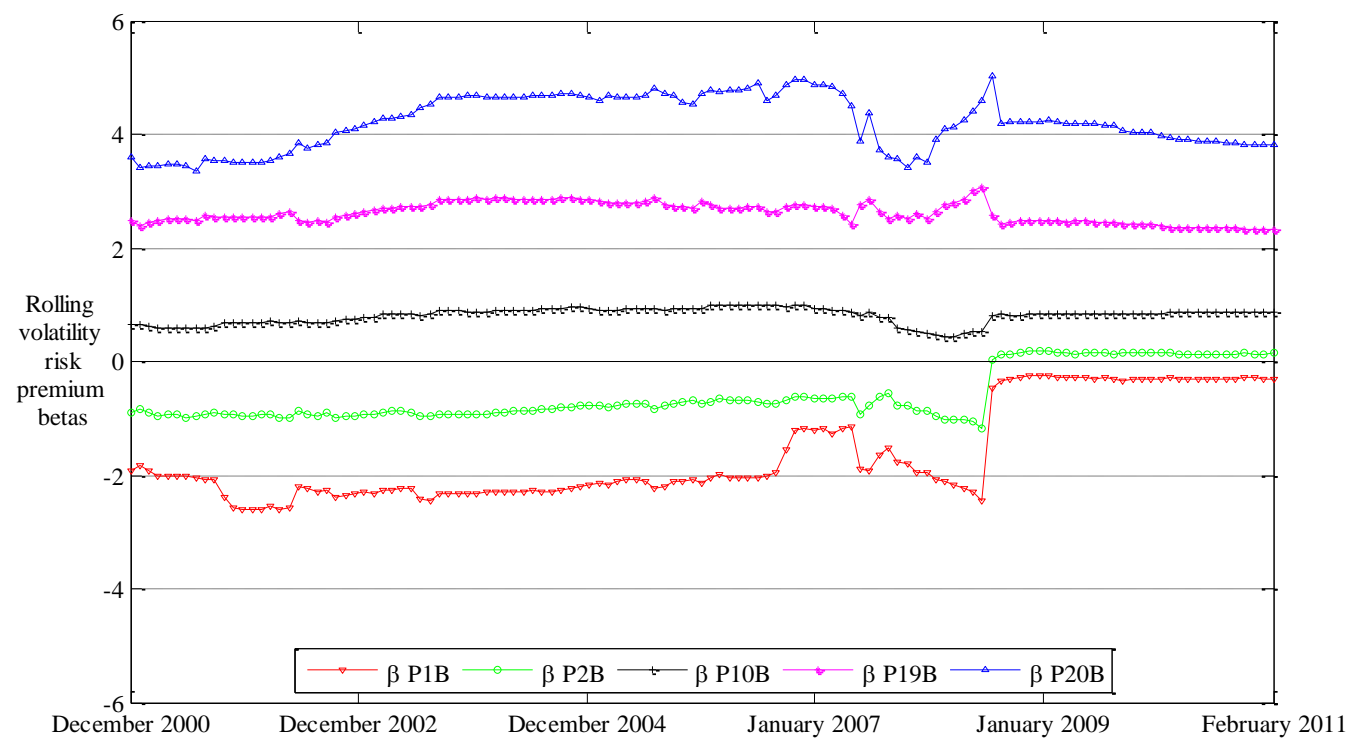

Panel B:

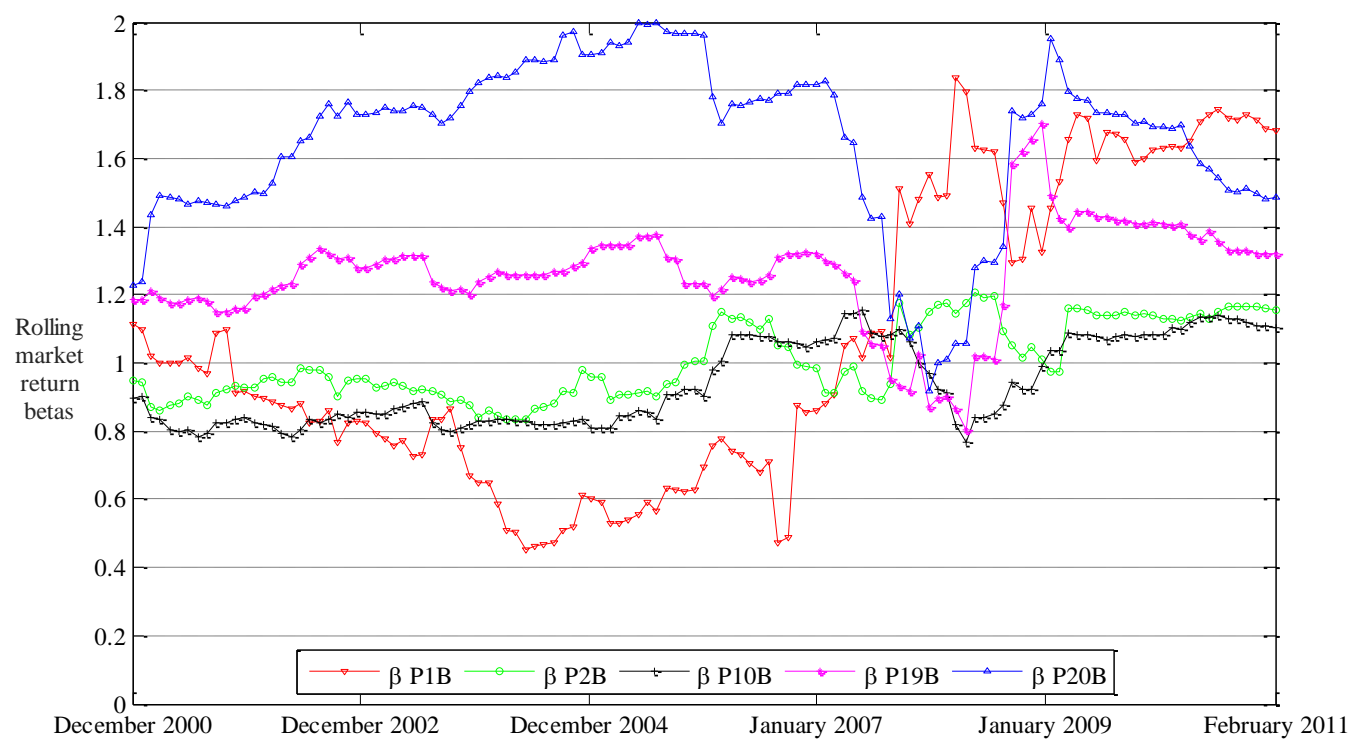

Fig. 2. Rolling volatility risk premium betas and market return betas. Panel A displays the rolling volatility risk premium betas for extreme and intermediate VRP beta-sorted portfolios from January 1996 to February 2011. Panel B shows the rolling market return betas for extreme and intermediate $V R P$ beta-sorted portfolios from January 1996 to February 2011. For Panels A and B, the rolling estimation employs 59 past monthly observations. 
Panel A:

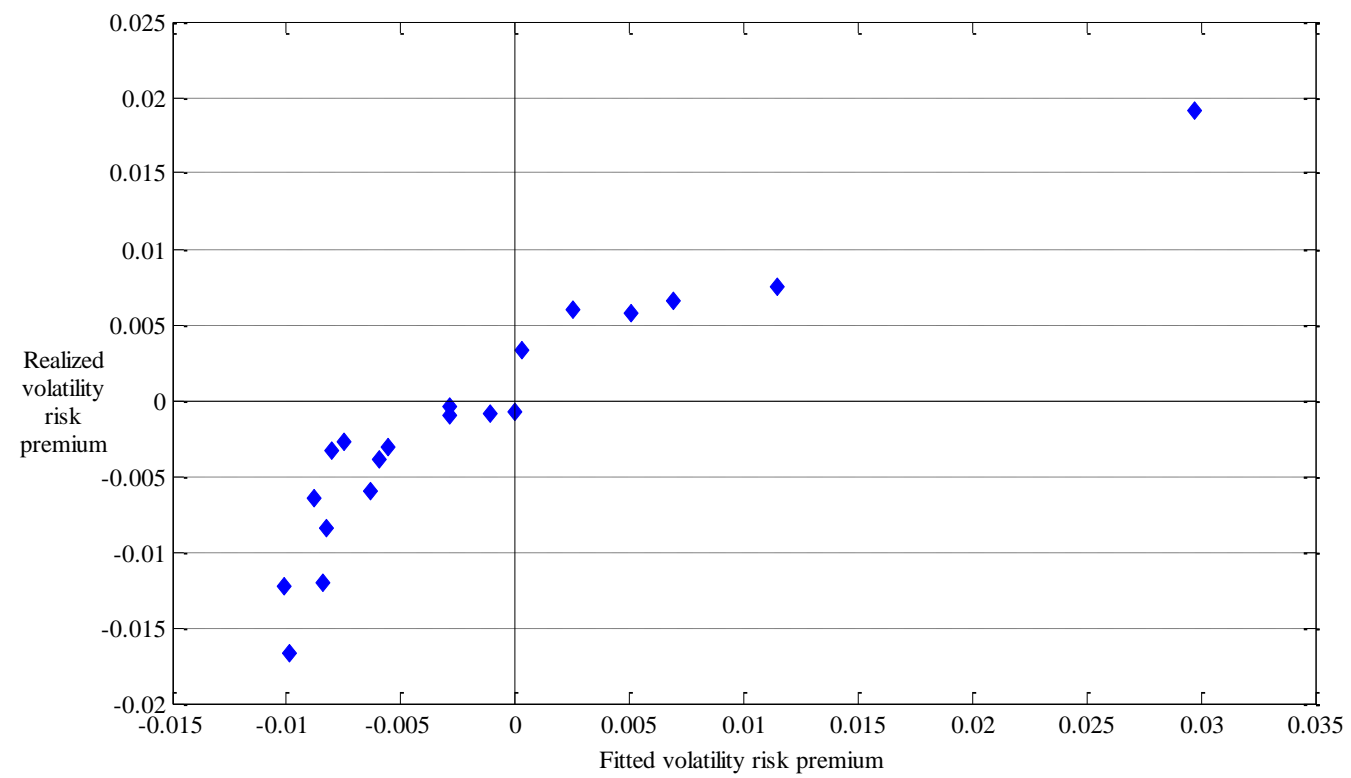

Panel B:

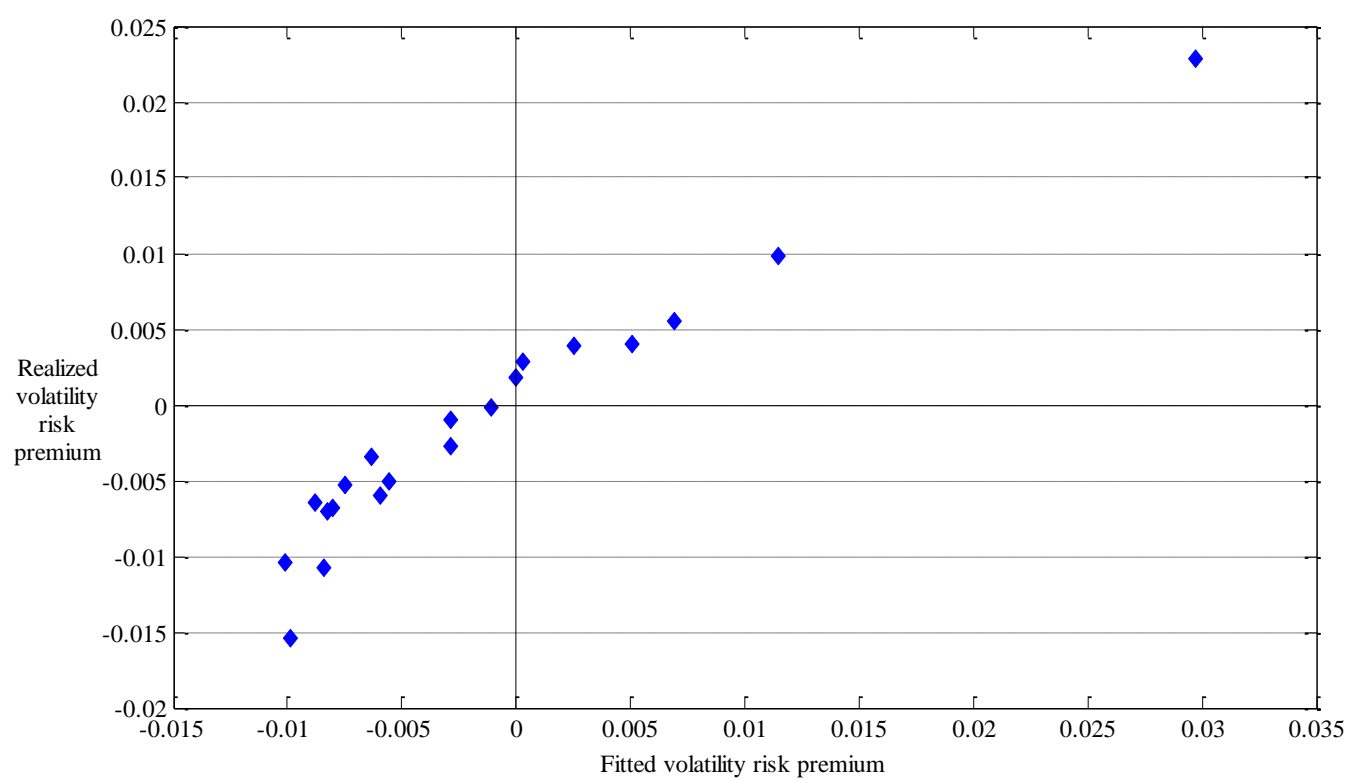

Fig. 3. Average returns versus average returns from the estimated parameters of the Fama and MacBeth twopass cross-sectional regression, volatility risk premium beta-sorted portfolios. Panel A displays the cross section of volatility risk premia with recursive preferences with market volatility risk premium and aggregate consumption growth from January 1996 to February 2011. Panel B shows the cross section of volatility risk premia with linear stochastic discount factor (SDF) with market volatility risk premium and default from January 1996 to February 2011. 